"نشريه علوم زراعى ايران"

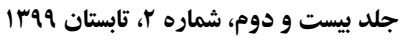

مقاله يُوهوشى

ارزيابى ساز كارى و يايدارى عملكرد دانه لاينهاى اميد بخش سويا (Glycine max L. Merril)

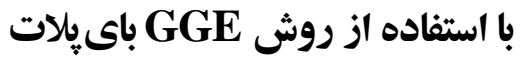

Evaluation of adaptability and seed yield stability of soybean

(Glycine max L. Merril) promising lines using GGE biplot analysis

حميدرضا بابائى '، نسرين رزمى '، ساميه رئيسى 'و حسين سبزى

جكيده

بابائى، ح.و.، ن. رزمى، س. رئيسى و ح. سبزى. و9 آ. ارزيابى ساز كارى و يايدارى عملكرد دانه لاينهاى اميد بخش سويا (Glycine max L. Merril) بـا استفاده از

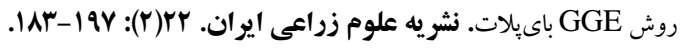

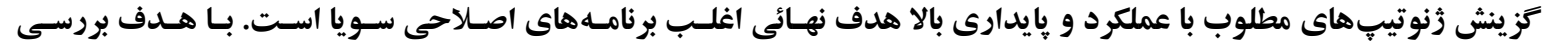

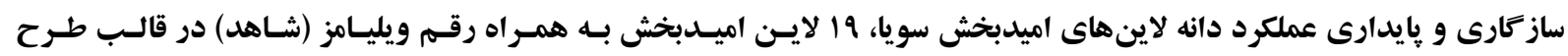

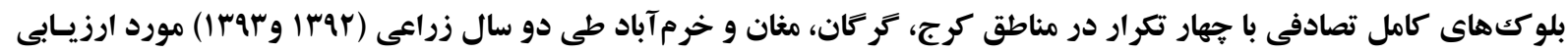

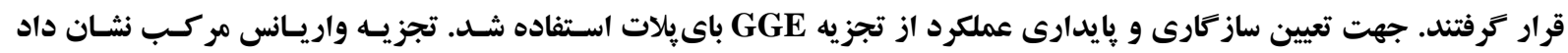

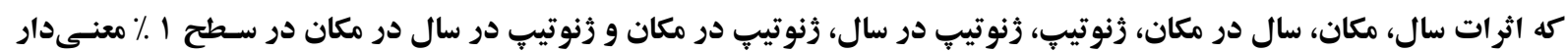

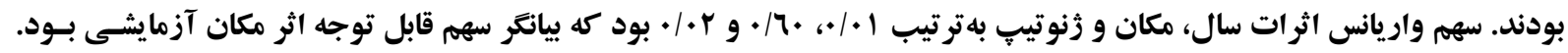

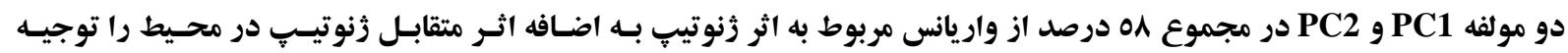

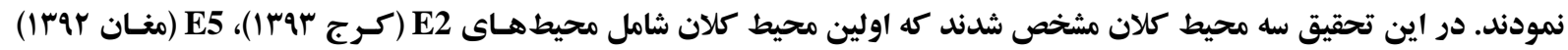

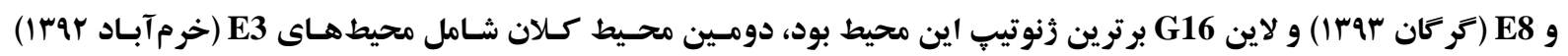

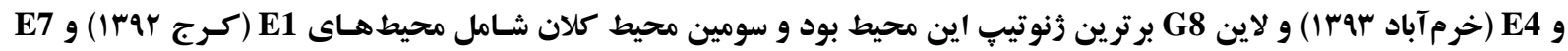

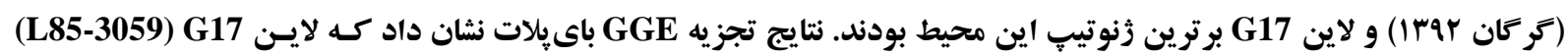

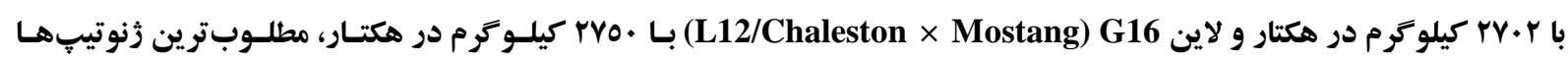

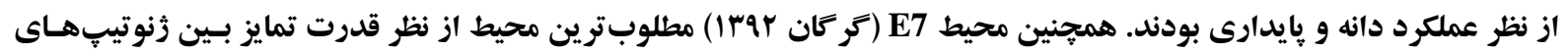
سويا و بهترين نماينده منطقه هدف در نظر كرفت.

وازههاى كليدى: اثر متقابل زنوتيب در محيط، تجزيه باى يلات، سويا، زنوتيٍ مطلوب و محيط مطلوب.

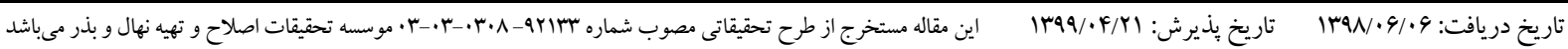

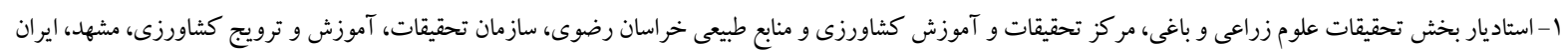

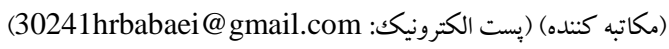
r- استاديار بخش تحقيقات علوم زراعى و باغى، مركز تحقيقات و آموزش كشاورزى و منابع طبيعى اردبيل (بارس آباد مغان)، سازمان تحقيقات، آموزش و ترويج كشاورزى، يارس آباد مغان، ايران

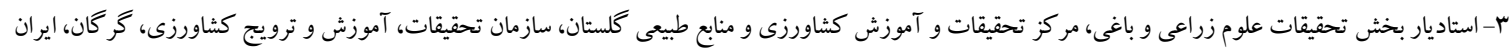

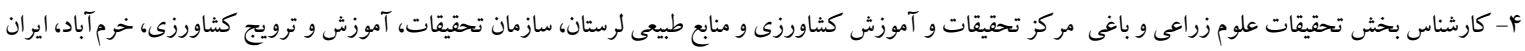


مفيـدى در خصـوص زَنوتيـٍِهـا و محسيطهـاى مـورد بررسى در اختيار بهنزادكر قـرار مسىدهـد اثر محسيط در

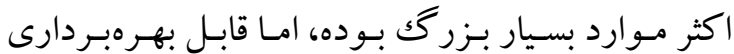
نيست، بنابراين حذف اثر محيط از دادههـا و تمر كـز بـر اثر زنوتيب و اثر متقابل "زَنوتيّ × محيط" مفيد خواهـد بـود (Yan et al., 2007). در ايسن روش بـراى انتخـاب زنو تيب مطلوب يكك زنوتيـٍٍ ايـدهآل فرضسى براسـاس عملكرد زنو تيبّها در محيطهاى مختلف تعيين مىشـود

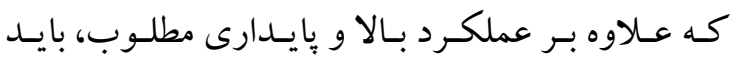
ساز گارى وسيعى در مناطق هدف نيـز داشـته باشـند. در نمودار باىيلات از نظر مكانى در مركز دوايسر همر كـز قرار دارد (Amira et al., 2013, Bhartiya et al., 2017)

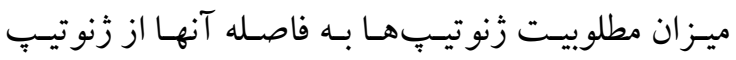

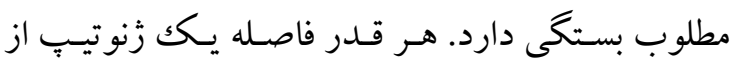

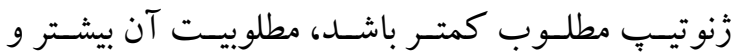
هرجقــــر ايسن فاصـله بيشـتر باشـــ مطلوبيـت آن كمتـر خو اهد بود. در روش GGE باى بيلات همجِنسين مىتـوان

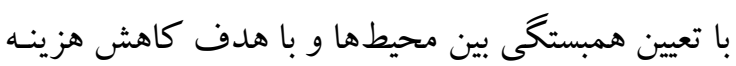
آزمايشات، محيطهاى مشابه را شناسايى و برخى از آنها را حسـف نمــود. در ايسن روش كسـينوس زاويـهـ بـين بردارهاى محيطى تقريبى از همبسـتكى بـين محـيطهـا است. زمانى كه زاويه بـين دو بـردار محيطى .9 درجـه باشد، همبستكى آنها صفر و اكر اين زاويه صـفر درجـه

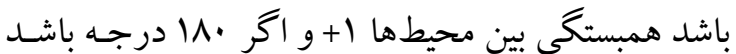
همبسـتخى 1- خو اهــد بـود (Yan and Kang, 2003). ويز گى مهم ديخر در باى بلات همبستخى بين محيطهـا، طول بردار محيطى اسـت كـه تقريبى از انحـراف معيـار درون هر محيط و نيـز شاخصسى بـراى " قابليـت تمـايز " محسيطهـا محسـوب مى شـود. بـهــورى كـه بردارهـاى

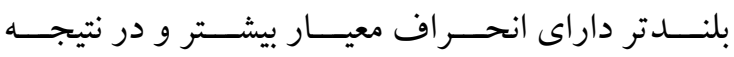
دار ایى قابليـت تمـايز بيشـترى هســتند. محيطهــاى بــا

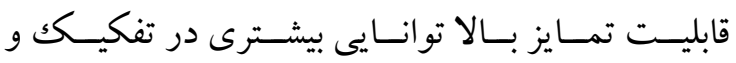
شناسايى زنوتيٍٍ هاى برتر بر اساس عملكردشـان دارنـد (Yan and Kang, 2003, Alake and Ariyo, 2012 ;

\section{مقدمه}

كياه روغنى سويا ( Glycine max) بهدليل سـاز گارى بـالا در دامنسه وسـيعى از عرضهـاى جغر افيـايى در دنيـا كشت و كار مى شود. در اغلب مزارع سـويا در ايـران از ارقام تجارتى استفاده مىشود كه از برنامـههاى بـهنزادى (Babaei et al., 2016). داخـل كشـور بدست آمدهانـــ وجود اثر متقابل زنوتيّ در محيط بـراى صـفات كمسى

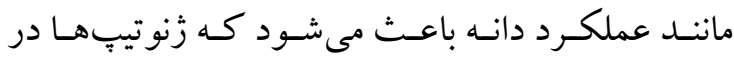
محيطهاى مختلف عملكرد نسبى مشابهى نداشته باشـند. روش هـاى آمـارى بسـيارى مانـــد تجزيسه واريـانس و

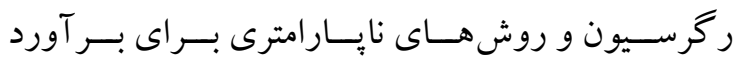
اثرهاى اصلى زَنوتيـبٍ، محسيط، اثـر متقابـل زنوتيـبِ در

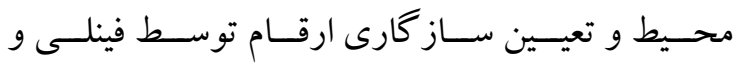
ويلكينسون (Finlay and Wilkinson, 1963) و ابرهـارت و راسل (Eberhart and Russel, 1966) معرفى و مـورد اسـتفاده قرار خرفتـه اسـت. در بسـيارى از ايسن روشهـا برخسى از فرضـيات اساسـى تجزيسه بايــدارى از جملـه

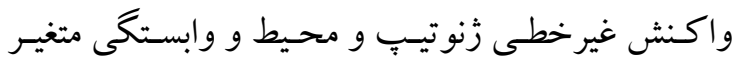

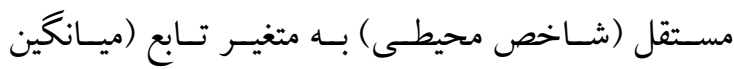
زَنو تي״ها) صادق نيست (Basford and Cooper, 1998). با استفاده از روش هاى جنــد متغيـره از جملـه تجزيـه بـــ مؤلفـههاى اصسلى و تجزيسه اثـرات اصـلى جمع يـذير و (Additive main effect and اتـرات متقابـل ضـربـيذير multiplicative interaction; AMMI) ضرب يذير زَنوتيسِ در محسط را تجزيسه و مقـدار آن را

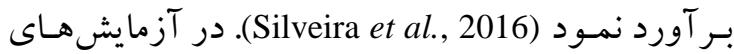

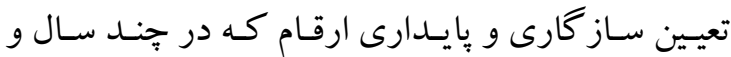
مكان اجرا مى شـود، مى تـوان بـا اسـتفاده از روش GGE باى بِات و با لحاظ نمودن اثر اصلى زنوتيّ (G) و اثر متقابل زُنوتيب در محيط (GE)، دو مؤلفه PC1 و PC2 را تعريف نمـوده و همزمـان عملكـرد و يايسدارى ارقـام را مـورد ارزيـابى قـرار داد (Yan and Kang, 2003). روش

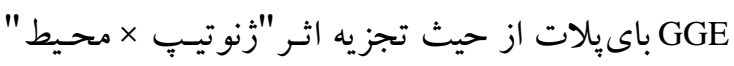
موفقتر و كار آمــدتر از روش AMMI بـوده و اطلاعـات 
4r زنو تيبّ سـويا در سـه مكـان بـا عرضهـاى مختلـف

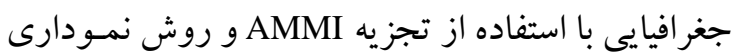

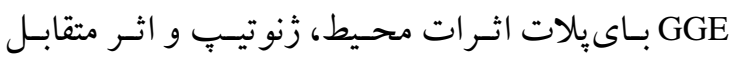

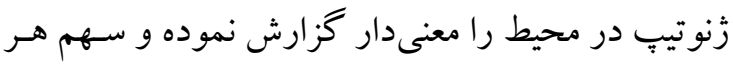

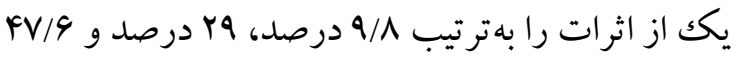

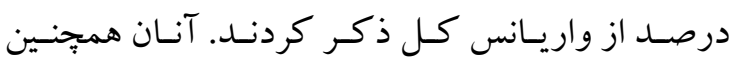

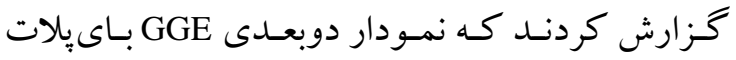

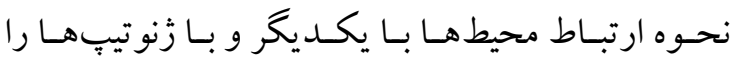

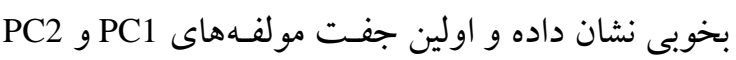

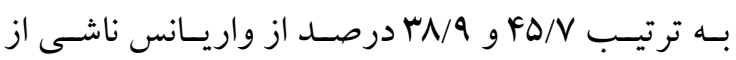

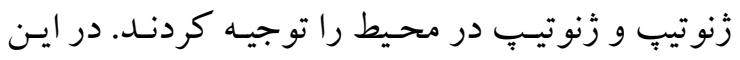

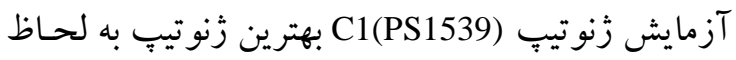
عملكرد بالا و حداقل اثـر متقابـل شـناخته شــــ سـيلويرا

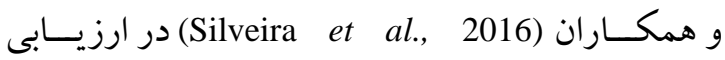

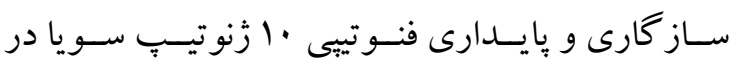

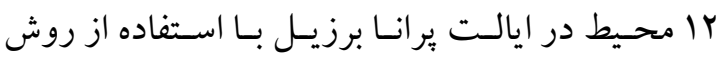

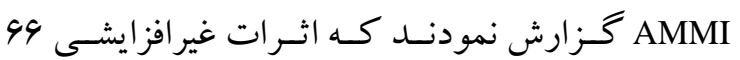
درصد از واريانس كل را تشكيل دادند كه از ايسن ميـزان

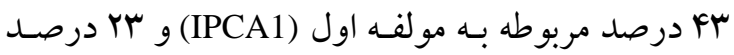
مربسوط بـه مولفـه دوم (IPCA2) بـوده اسـت. در ايسن آزمايش زنو تيبه هاى SYN1059، و و SYN1163

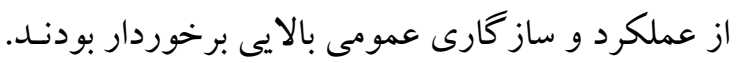
جادارى و وه ( Chaudhary and Wu, 2012 در ارزيـابى سـاز كارى ها زنوتيـبِ سـويا در شـش مكـان از نـواحى شرقى ايالت داكو تاى جنوبى با استفاده از روش تجزيـه نشان دادند كه اجزاى واريانس اثرات رنوتيب و اثر متقابل زنوتيّ در محيط بـراى سـه صفت عملكـرد

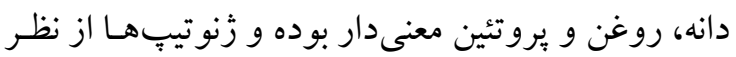

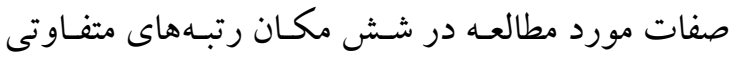

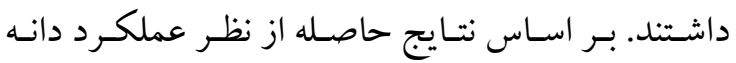

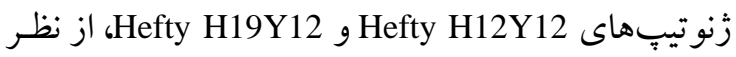

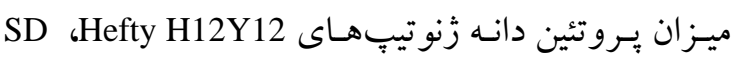

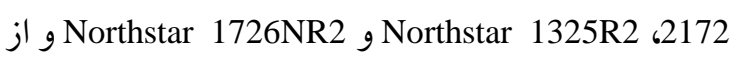

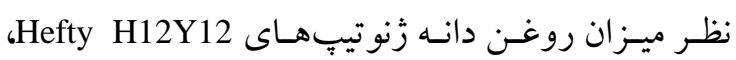

يكى ديخـر از ويز كىهـاى مهـم .Amira et al., 2013) "ميزان بيانگرى" يا نمايندگى محيط آزمايشى از منطقه دئه

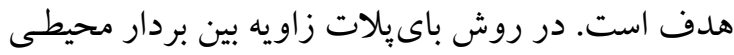

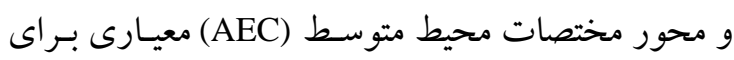

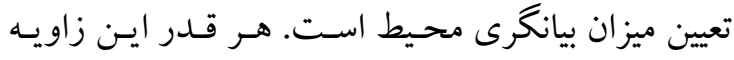

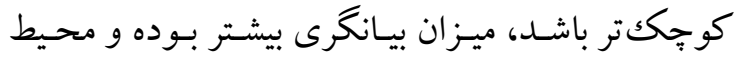

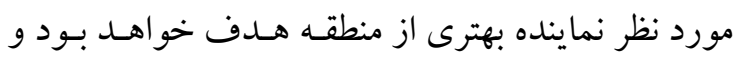

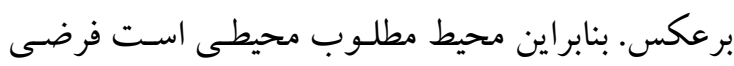

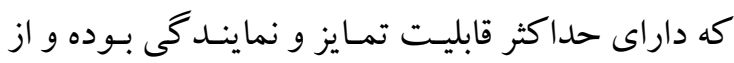

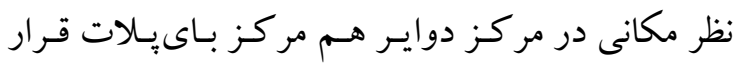

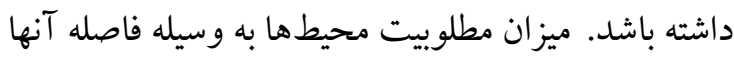
از محيط مطلوب سنجيده مىشود. هر اندازه يكك محيط

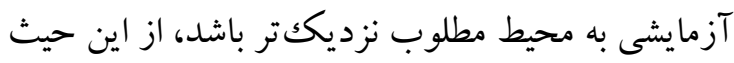

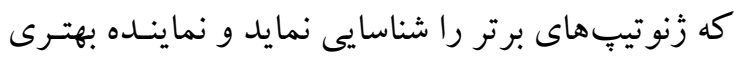

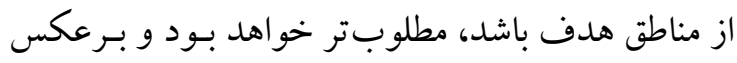
هر اندازه از محيط مطلوب فاصله بيشـترى داشـه باشــا، نما ينـده مناسبى از منـاطق هـدف نبـوده و بــدين جهـت

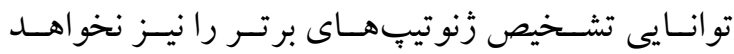
داشت (Jandong et al., 2011; Yan et al., 2003). آتنف و همكاران (Atnaf et al., 2013) در آزمايشى بـه

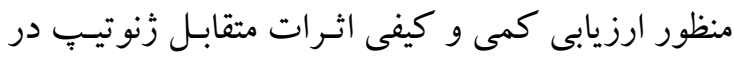

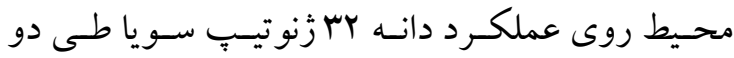

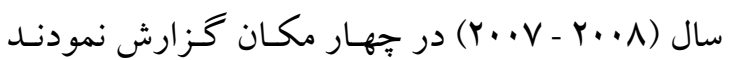

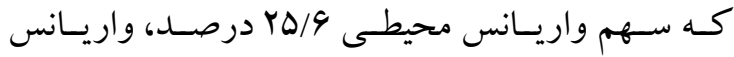
زنو تييى أl أدرصد و واريانس اثر متقابـل زنوتيـٍ در

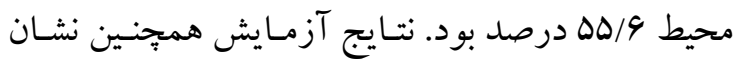

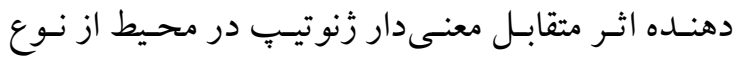

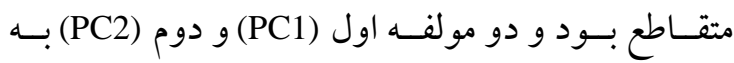

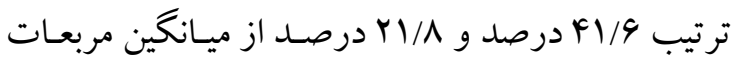

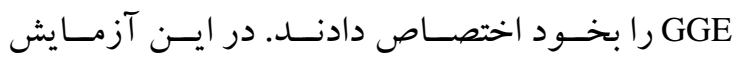

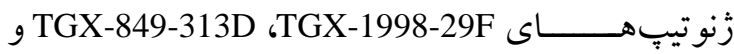
TGX-1889-29F با توجه به عملكرد و ويايـدارى بـالا بـه

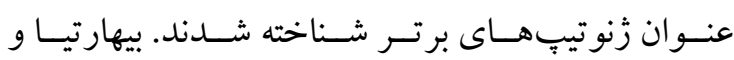

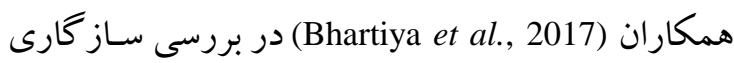


جهـار منطقـه كرج، گر گــان، مغـان و خرم آبـاد مـورد

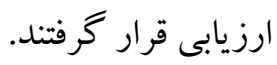

\section{مواد و روشها}

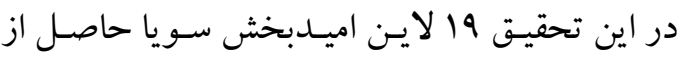

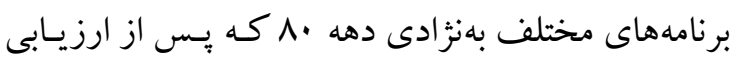

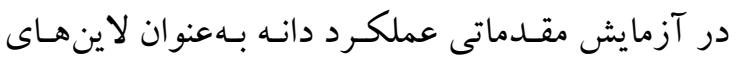
اميدبخش برتر انتخاب شده بودند به همراه رقـم ويليـامز

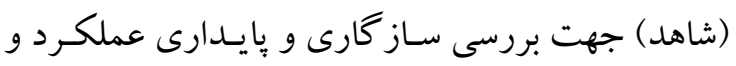

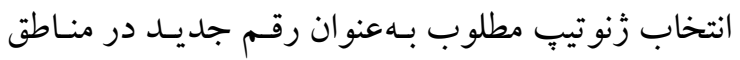

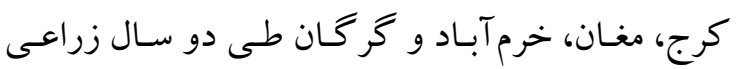

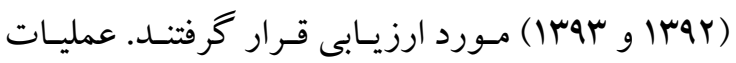

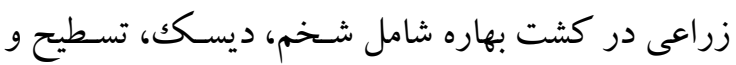

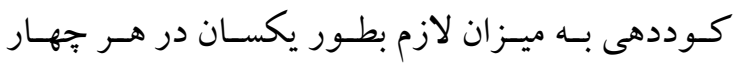

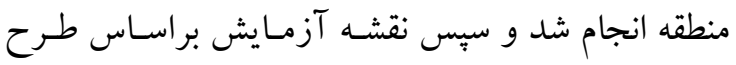

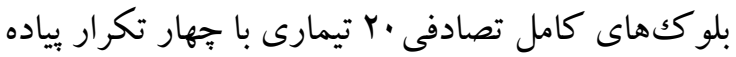

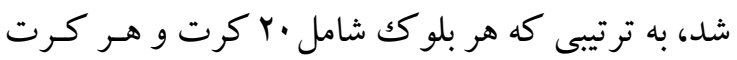
4. ، 4هل جهار رديف جهار مترى با فواصل بين رديـف

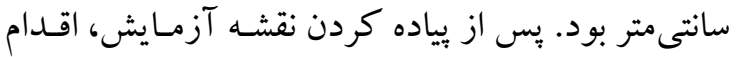

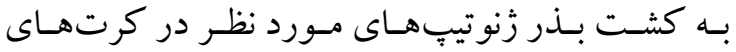
مربوطه شد. عمليات داشت و مر اقبتهـاى زراعى لازم

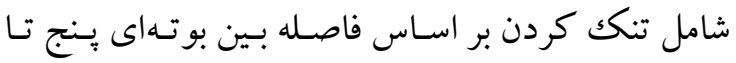

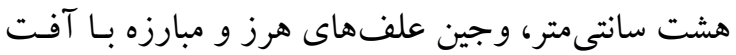
ترييس (در صورت لزوم) و آبيارى در طول دوره رشـــ

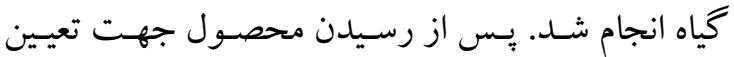

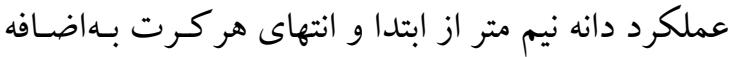
دو رديف حاشيه حـذف و محصـول بقيه كرت معـادل ه/9 متر مربع برداشت و يس از توزين بهعنوان عملككرد

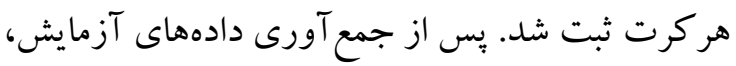

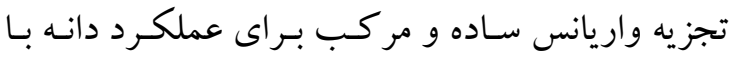

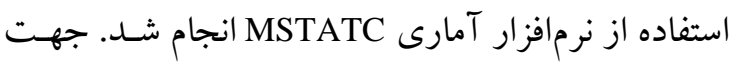

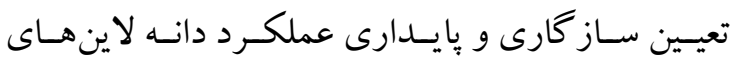

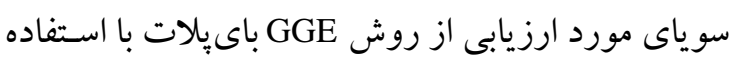
از نرمافزار 12 Genstat انجام شد (Payne et al., 2009).
Nutech 6145 از سـاز گارى عمـومى بـالايى در منـاطق مورد بررسى برخـوردار بودنـــ. يـورداد و جمشـيدمقدم (Pourdad and Jamshid-Mogaddam, 2013) ساز كارى نه رقم كلزا در نه محيط گَزارش كردنــ كـهـ

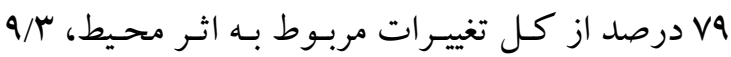

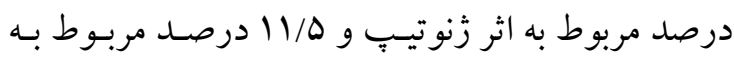

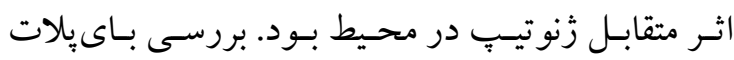

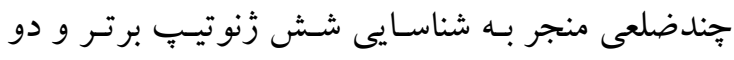

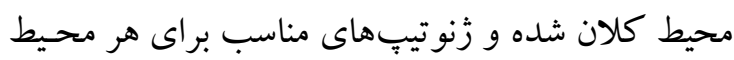

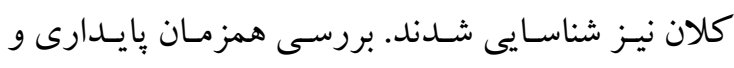

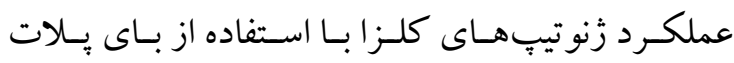

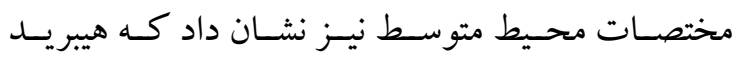

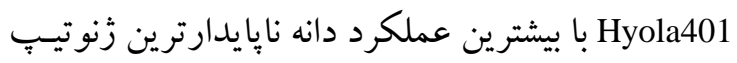

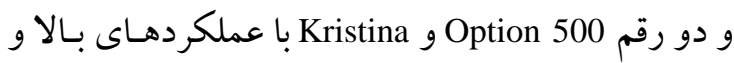

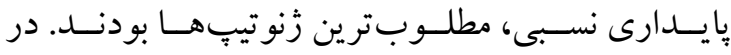

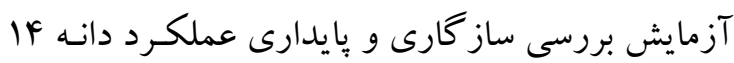

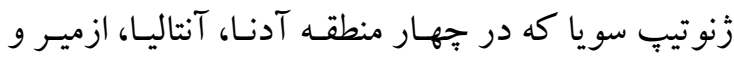

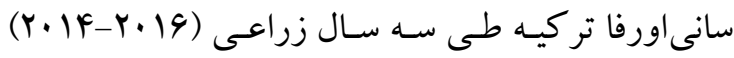

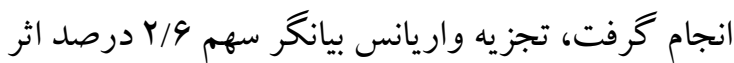
زُنو تيبّ و اله درصـد اثر محيط از واريـانس كل بـوده،

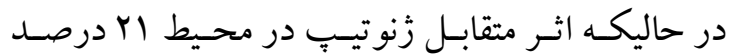
از واريانس كل را بهخود اختصاص داد. در تجزيـه GGE

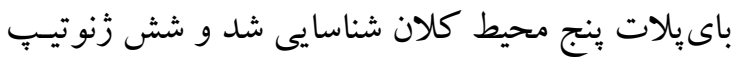
‘BATEM306 ‘ARISOY ‘KASM02 ‘KANA

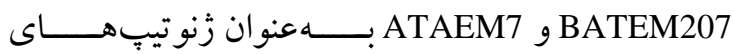
هايدار و BAEM317 باتو جه به عملكرد دانسه و مجمسوع

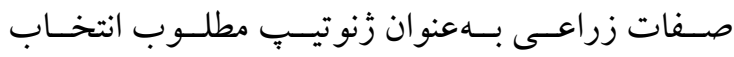
شدند (Kocaturk et al., 2019). در تحقيـق حاضـر بــا هـــف معرفـى يـك لايسن

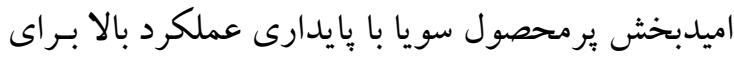

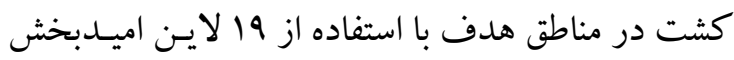

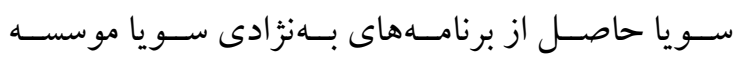

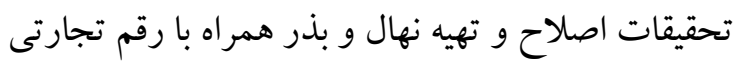

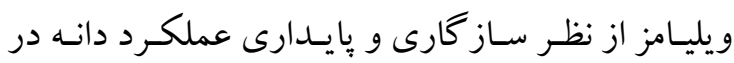




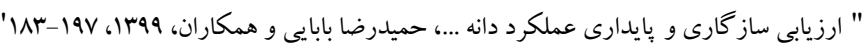

جدول ا- اطلاعات اقليمى مكانهاى اجراى آزمايش

Table 1. Climate parameters of experiment locations

\begin{tabular}{|c|c|c|c|c|c|}
\hline Parameters & آماره & Karaj & $\begin{array}{c}\text { كر كان } \\
\text { Gorgan }\end{array}$ & $\begin{array}{c}\text { مغان } \\
\text { Moghan }\end{array}$ & $\begin{array}{c}\text { خرمآباد } \\
\text { Khorramabad }\end{array}$ \\
\hline Altitude (m) & ار تفاع از سطح دريا & 1321 & 155 & 45 & 1155 \\
\hline Latitude & عرض جغرافيايى & $35.49^{\circ} \mathrm{N}$ & $36.83^{\circ} \mathrm{N}$ & $39.30^{\circ} \mathrm{N}$ & $33.26^{\circ} \mathrm{N}$ \\
\hline Longitude & طول جغرافيايى & $51.06^{\circ} \mathrm{E}$ & $54.48^{\circ} \mathrm{E}$ & $47.20^{\circ} \mathrm{E}$ & $48.17^{\circ} \mathrm{E}$ \\
\hline Total Rainfall (mm) & ميانگين بارندگى ساليانه & 240 & 700 & 300 & 499 \\
\hline Average Temp $\left({ }^{\circ} \mathrm{C}\right)(\max )$ & ميانكين حداكثر دما & 28 & 23 & 34 & 25.3 \\
\hline Average Temp $\left({ }^{\circ} \mathrm{C}\right)(\mathrm{min})$ & ميانگين حداقل دما & 1 & 12 & -0.7 & 9.1 \\
\hline
\end{tabular}

از تغييرات كل دادهها بود. اين نتايج نشان داد كـه سهم واريـانس مكانهـاى آزمايشـى ( •/9 •) بـه ميـزان قابـل توجهى بيشـتر از سـالها و زنوتيّهـاى آزمايشـى بـوده

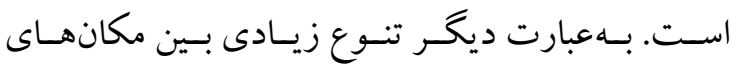
آزمايشى وجود داشته است.

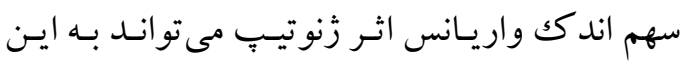

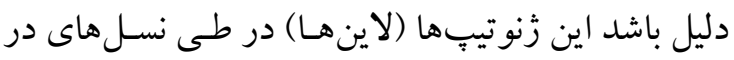
حال تفرق و آزمايشات مقدماتى عملكرد براى كـزينش لاينهاى بر محصول مورد ارزيابى قـرار كرفتهانسد و بـهـ

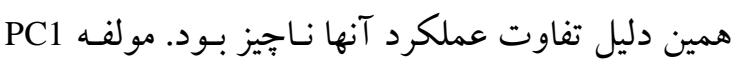

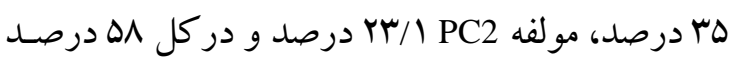
از واريانس مربوط به مجموع اثرات زنوتيـيٍ و زنوتيستِ در محيط (G+ GE) را توجيه نمودند (شكل ()). سيلويرا و همكــاران (Silveira \& et al, 2016) در ارزيـابى

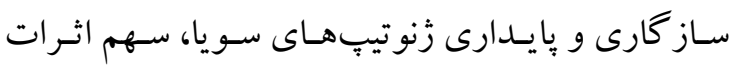
متقابل غير افزايشى از واريانس كل را 49 درصد و سـهم مولفه هاى اول و دوم از اثر متقابل را بهترتيب سم درصد

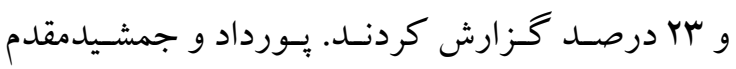
(Pourdad and Jamshid-Mogaddam, 2013) ساز گارى نه رقم كلزا در نه محيط كز ارش كردنـد كـه.

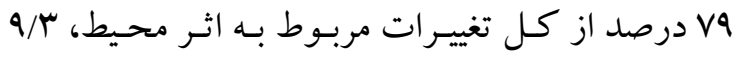
درصد مربوط به اثر زنوتيسّ و /1/1 درصـد مربسوط بـه

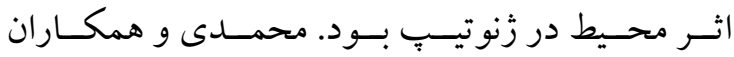
در تجزيـه اثرات متقابـل (Mohammadi et al., 2013)

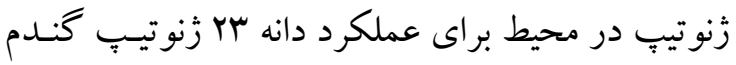
دوروم و نان در شرايط ديسم بـا اسـتفاده از تجزيـه GGE

\section{نتايج و بحث}

نتايج تجزيه واريانس ساده نشان داد كه اثـر زُنوتيـبّ

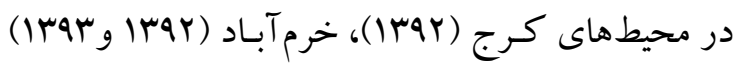
در سطح احتمال بنج درصد و محيطهاى كرج (سوب(I)،

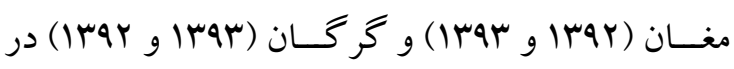
سطح احتمال يكك درصد معنىدار بود. تجزيه واريـانس مركب دو ساله هر محيط نشـان داد كـه اثـر زنوتيـبِ در هر جهار مكان در سطح احتمـال يـك درصـد معنى دار

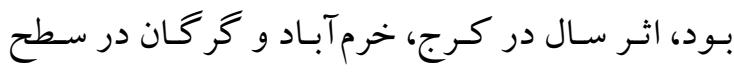
احتمال يكك درصد معنىدار و در مغان غير معنىدار بـود

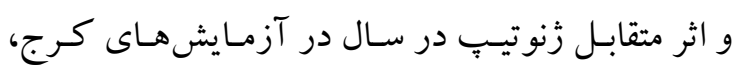
كر گان و مغان در سطح احتمال يكك درصد معنى دار و در خرم آباد غير معنى دار بـود. تجزيسه واريـانس مركـب دمبـ جهار مكان طى دو سال نيز نشان دهنده اثرات معنى دار كليسه منـابع تغيــر شـامل سـال، مكـان، سـال در مكـان،

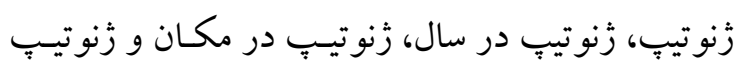
در سال در مكان بود. معنىدار شدن اثـرات زنوتيـبِ در محيط نشـان داد كـه تجزيـه يايسـارى بـا تفكيكك منـابع

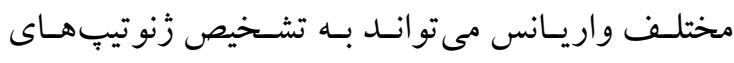

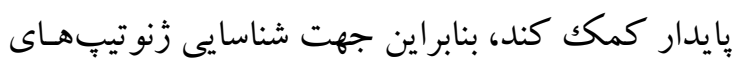

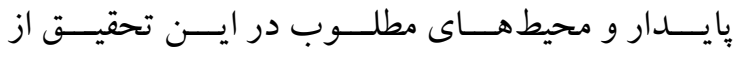
تجزيه GGE باى بالات استفاده شد. در اين تحقيـق سـهم

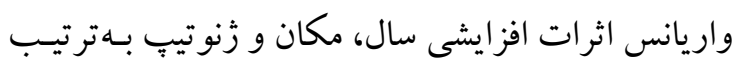

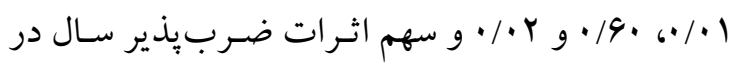

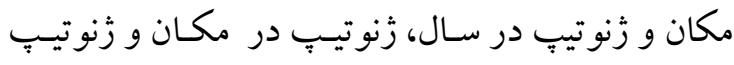

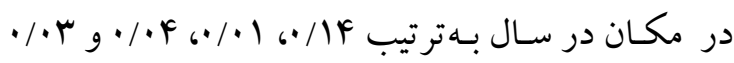




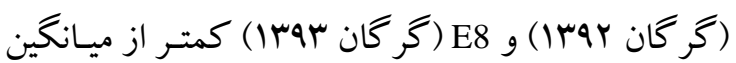

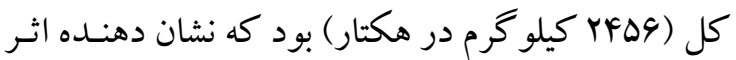
متقابل منفى زنوتيِّها با اين محيطهـا اسـت. در محسط

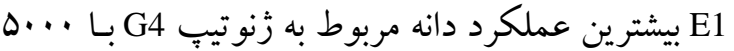
كيلـو گرم در هكتـار و كمتـرين عملكـرد دانسه بـا ساهـ كيلو گرم در هكتار مربوط به زنوتيب G9 بود. در محسيط

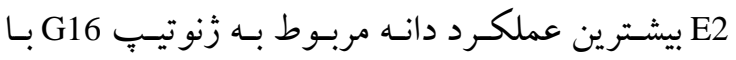
rAM كيلو كرم در هكتـار و كمتـرين عملكـرد دانسه بـه

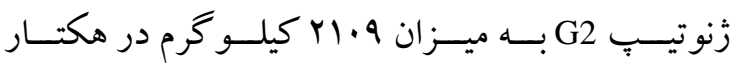
اختصاص يافت. در محيط E3 بيشترين عملكرد دانه بـه

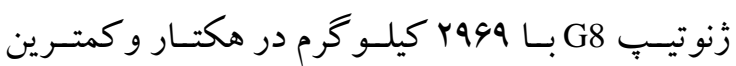
عملكرد دانسه بـا وهسا كيلـو گرم در هكتـار بـه زنوتيـتِ G10 اختصاص بيدا كرد. در محيط E4 بيشترين عملكرد

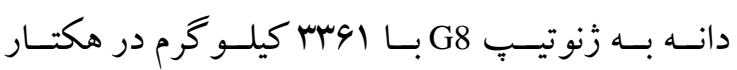

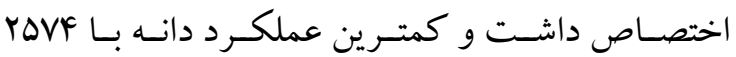

بـاى يـلات و ركرسـيون تـوام (ضـريب ركرسـيون +

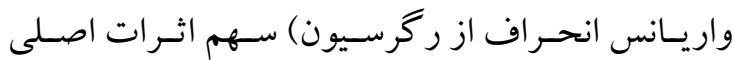

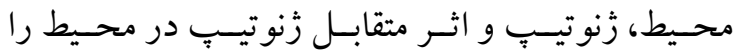

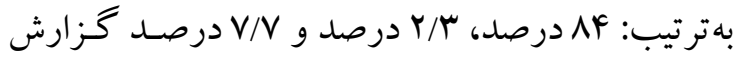
كردند. ميانگين عملكرد دانه زنوتيبِهـاى سـويا در هـر محيط، ميانگين عملكرد هـر زنوتيـبِ در كليـه محيطهـا،

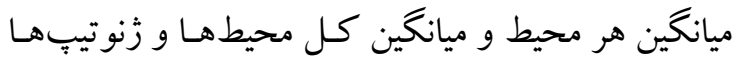
همراه با شناسـه زنوتيبهـا و محيطهـا در تجزيـه باى بِات در جدول r ارائه شده است. بـر اسـاس نتـايج،

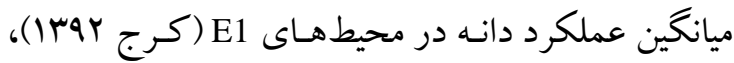

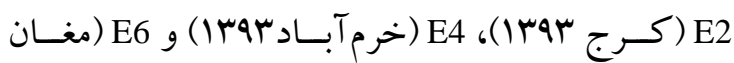

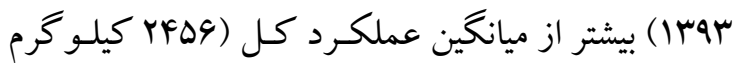
در هكتـار) بــود كـه نشـان دهنــده اثـر متقابـل مثبـت زَنو تيڤها با اين محيطها مىباشد. ميـانگين عملكرد در

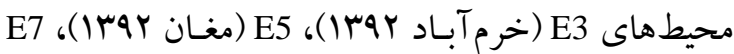

جدول r - ميانگين عملكرد دانه (كيلو گرم در هكتار) لاينهاى اميدبخش سويا در محيطهاى آزمايشى و ميانگين كل

Table 2. Mean grain yield $\left(\mathrm{kg} \cdot \mathrm{ha}^{-1}\right)$ of soybean pure lines in the experimental environments and total mean

\begin{tabular}{|c|c|c|c|c|c|c|c|c|c|c|c|}
\hline \multirow{4}{*}{ رديف } & \multirow[b]{3}{*}{ شناسه } & & \multicolumn{2}{|c|}{ Kرج } & \multicolumn{2}{|c|}{$\begin{array}{c}\text { خرم آباد } \\
\text { Khoramabad }\end{array}$} & \multicolumn{2}{|c|}{$\begin{array}{c}\text { مغان } \\
\text { Moghan }\end{array}$} & \multicolumn{2}{|c|}{$\begin{array}{c}\text { G } 5 \\
\text { Gorgan } \\
\end{array}$} & \multirow{4}{*}{$\begin{array}{l}\text { ميانگين } \\
\text { Mean }\end{array}$} \\
\hline & & & Irar & irar & irar & Irar & Irar & Irar & Irar & Irar & \\
\hline & & & 2013 & 2014 & 2013 & 2014 & 2013 & 2014 & 2013 & 2014 & \\
\hline & Code & Pedigree & (E1) & (E2) & (E3) & $(\mathrm{E} 4)$ & (E5) & (E6) & (E7) & $(\mathrm{E} 8)$ & \\
\hline 1 & G1 & L3 (Hacheston×L16) & 3603 & 2177 & 1643 & 2691 & 2239 & 1922 & 1195 & 1535 & 2126 \\
\hline 2 & $\mathrm{G} 2$ & L9 (Hacheston×L16) & 3786 & 2109 & 2031 & 2836 & 2233 & 2180 & 1661 & 1840 & 2334 \\
\hline 3 & G3 & L8 (Hacheston×L16) & 4086 & 1990 & 2482 & 3069 & 2540 & 2117 & 1079 & 1302 & 2333 \\
\hline 4 & G4 & L2 (Liana×L32) & 5000 & 2490 & 2172 & 2914 & 2193 & 1908 & 1632 & 2015 & 2540 \\
\hline 5 & G5 & L13 (Hacheston×L16) & 4511 & 2880 & 2242 & 2925 & 1771 & 2481 & 1637 & 2115 & 2570 \\
\hline 6 & G6 & L16 Hacheston×L16) & 4844 & 2822 & 2099 & 2839 & 2224 & 2010 & 1571 & 2121 & 2566 \\
\hline 7 & G7 & L17 (Hacheston×L16) & 4571 & 3363 & 1745 & 2627 & 2266 & 2198 & 1644 & 2167 & 2573 \\
\hline 8 & G8 & L3 (Liana×L32) & 4254 & 2560 & 2969 & 3361 & 2516 & 1960 & 1213 & 2074 & 2613 \\
\hline 9 & G9 & L2 (Kotaman $\times$ Kitamishiro) & 3513 & 2821 & 1862 & 2728 & 2327 & 3172 & 1012 & 1820 & 2407 \\
\hline 10 & G10 & L3 (Stressland × NMSB) & 4417 & 2740 & 1396 & 2574 & 2536 & 2539 & 1525 & 2359 & 2510 \\
\hline 11 & G11 & L5 $($ Stressland $\times$ NMSB $)$ & 4374 & 2302 & 2096 & 2838 & 1761 & 2525 & 1415 & 1835 & 2393 \\
\hline 12 & G12 & L6 $($ Stressland $\times$ NMSB $)$ & 4599 & 2278 & 1947 & 2733 & 1590 & 2570 & 1329 & 1730 & 2347 \\
\hline 13 & G13 & L8 $($ Stressland $\times$ NMSB $)$ & 3948 & 2780 & 1805 & 2788 & 2560 & 2137 & 1323 & 2320 & 2457 \\
\hline 14 & G14 & L1 (Spry ×Nemaha) & 4047 & 2640 & 1844 & 2780 & 2228 & 2370 & 992 & 2105 & 2376 \\
\hline 15 & G15 & L13 (Chaleston×Mostang) & 3981 & 2531 & 1776 & 2802 & 2586 & 2588 & 1217 & 2360 & 2480 \\
\hline 16 & G16 & L12 (Chaleston×Mostang) & 4225 & 3483 & 2255 & 2933 & 2349 & 2457 & 1725 & 2575 & 2750 \\
\hline 17 & G17 & L85-3059 (Aline) & 4190 & 3045 & 2664 & 3178 & 2375 & 2080 & 1332 & 2753 & 2702 \\
\hline 18 & G18 & LS (M50 × Williams) & 4161 & 3036 & 2151 & 2996 & 2403 & 2657 & 1103 & 1785 & 2536 \\
\hline 19 & G19 & LS $($ Columbus $\times$ Williams $)$ & 3912 & 2407 & 1794 & 2688 & 1617 & 2328 & 938 & 1580 & 2158 \\
\hline 20 & G20 & Williams (Check) & 3891 & 2626 & 1940 & 2994 & 2037 & 2332 & 1426 & 1555 & 2350 \\
\hline Mean & ميانخين & & 4196 & 2654 & 2046 & 2865 & 2217 & 2488 & 1348 & 1997 & 2456 \\
\hline
\end{tabular}


يكك نماى هشت ضلعى بـر اكنش زنو تيبهــاى سـويا بـر

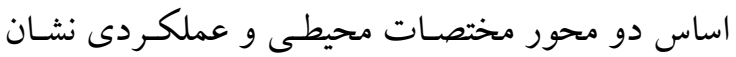

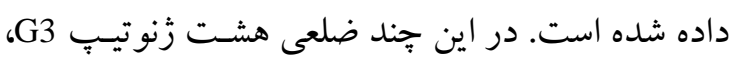

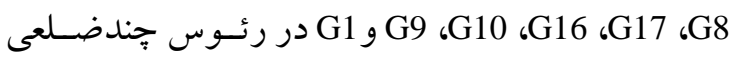

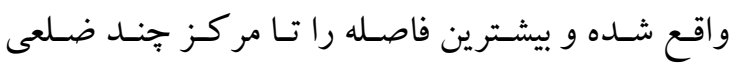

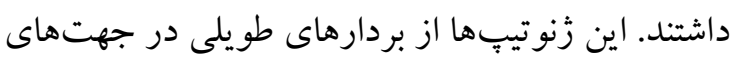

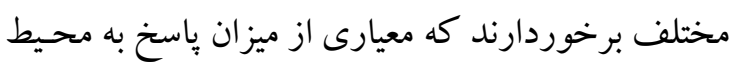

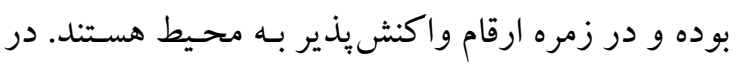

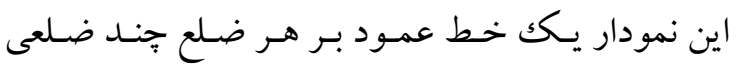

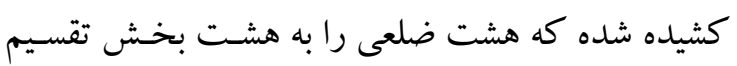

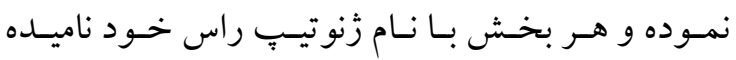

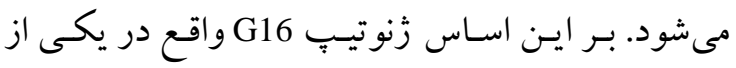

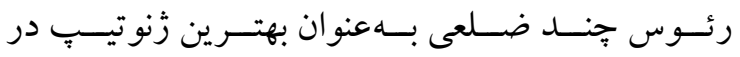

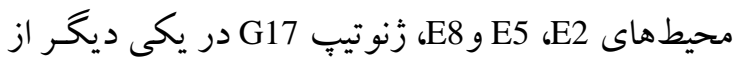
رئوس جندضلعى بهعنوان بهترين زنوتيب در محيطهاى

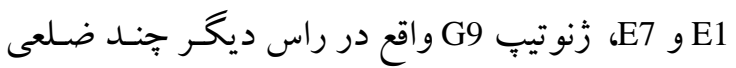

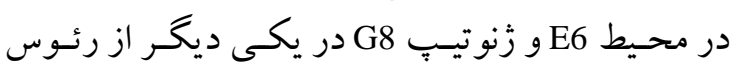

كيلـو گرم در هكتـار مربـوط بـهـ زنوتيـبـG10 بـود. در

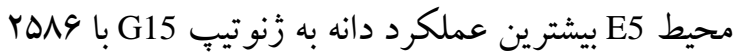

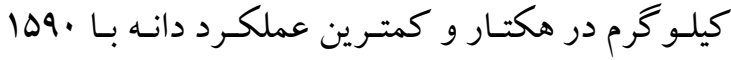

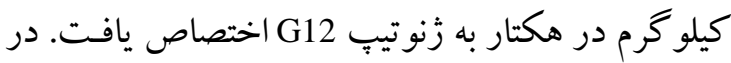

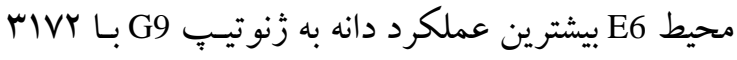

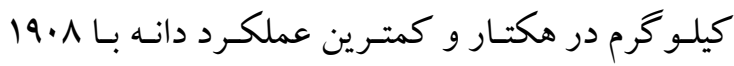

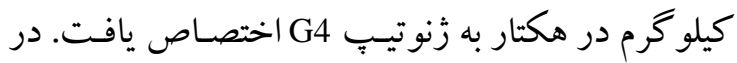

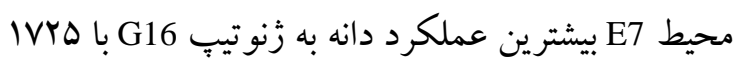

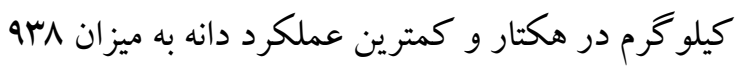

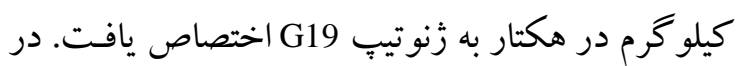

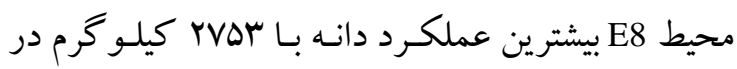

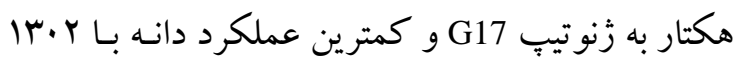

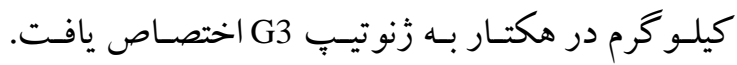

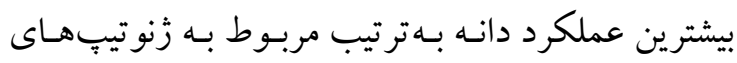

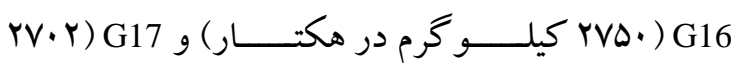

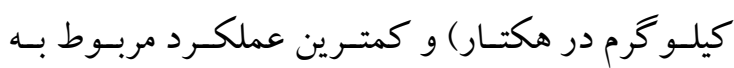

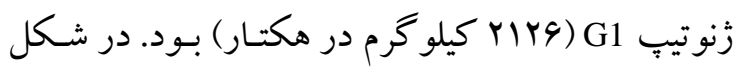

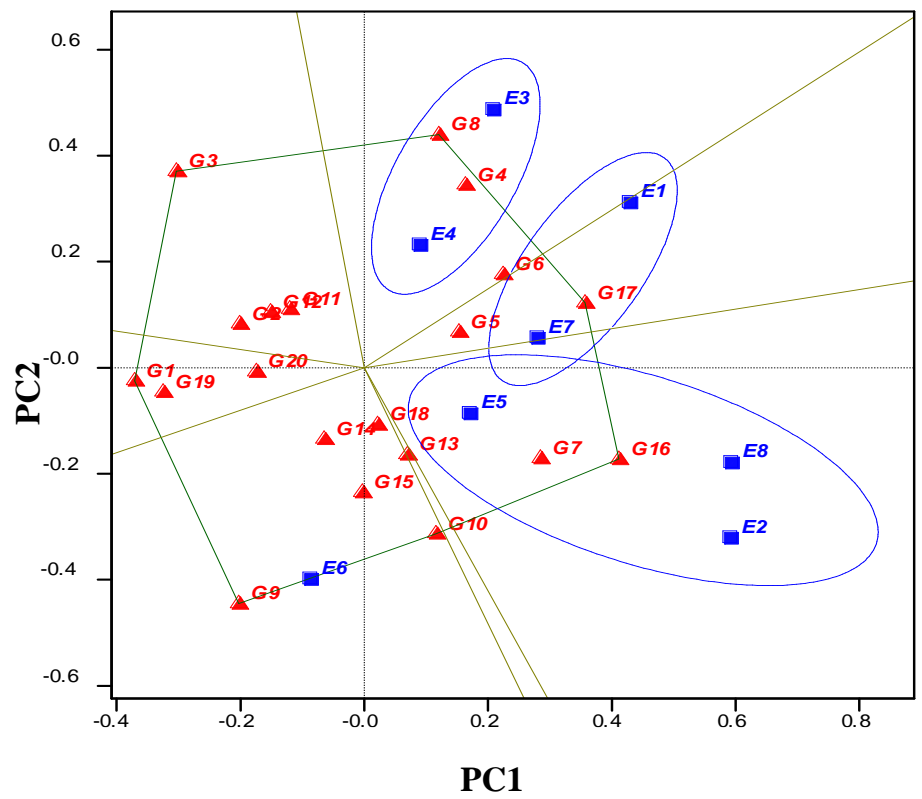

شكل 1- جندضلعى GGE باى يلات بر اساس عملكرد دانه لاين هاى اميدبخش سويا در جهار محيط آزمايشى هه درصد

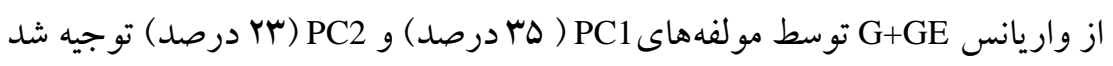

Fig. 1. GGE biplot polygon based on the performance of soybean purelines in four experimental environments $58 \%$ of GGE variance was explained by PC1 (35\%) and PC2 (23\%) components 
محسور افقى بيكـاندار كـهـ از ميـانگين محيطى (دايـره

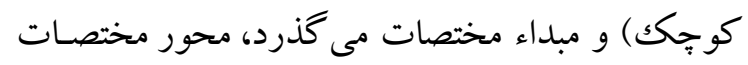

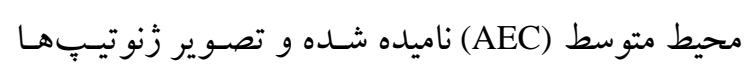

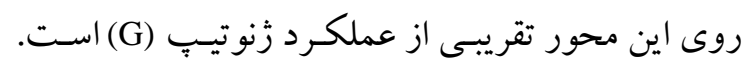

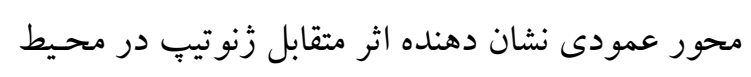

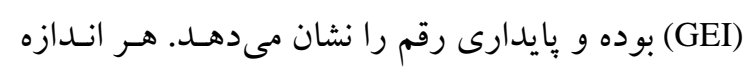

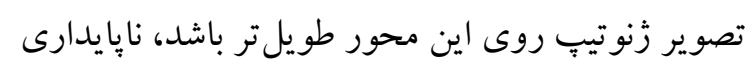

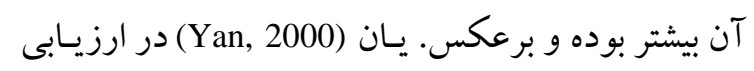

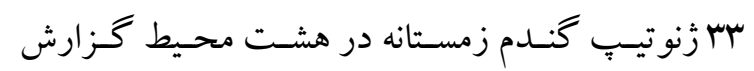

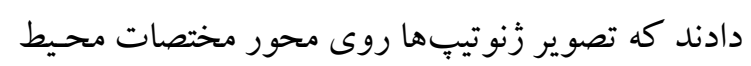

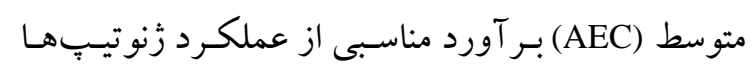

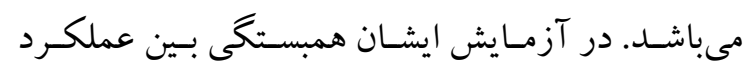

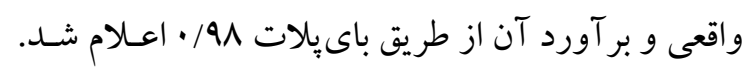

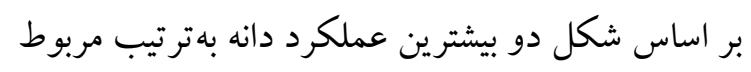

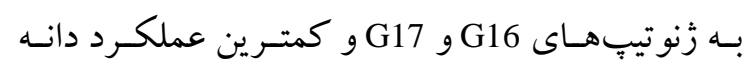

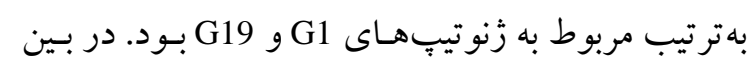

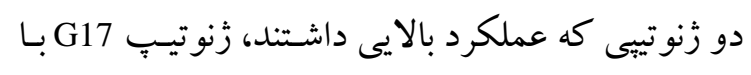

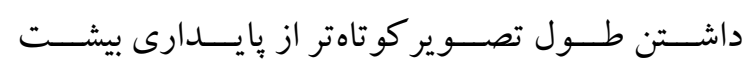

جندضـلعى در محيطهــاى E3 و E4 بــهنعنوان بهتــــين زنو تيبِها محسوب مىشوند. زنوتيبِهاى G1 و G3 نيـز

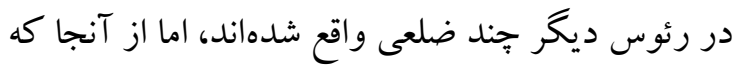
هيج محيطى در بخشها مربوط بـه ايسن زنوتيبِهـا قـرار

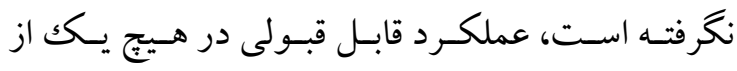
محيطهــاى آزمايشـى نداشـتند (شــكل () و و بــالاخره

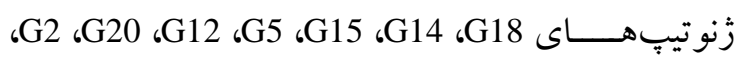

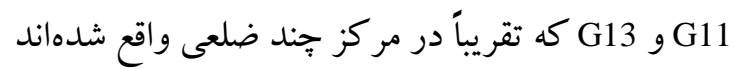

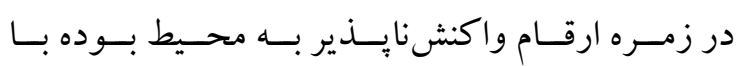
داشتن عملكرد متوسط در اغلب محيطها واكـنش نسبـا

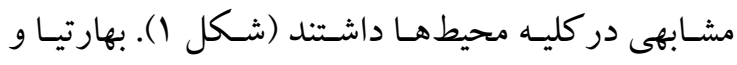
همكاران (Bhartiya et al., 2017) و راموس و همكاران (Ramos et al., 2017) تجزيه GGE باى يلات زنو تيبٍهاى سويا در هشت بخش

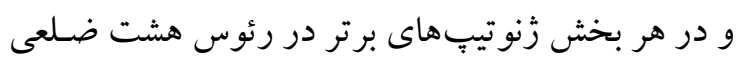
قرار گرفتند. در شكل دو باى يلات بررسى همزمان عملكرد دانسه

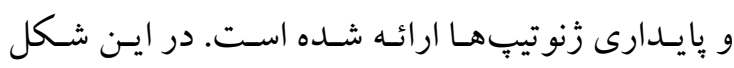

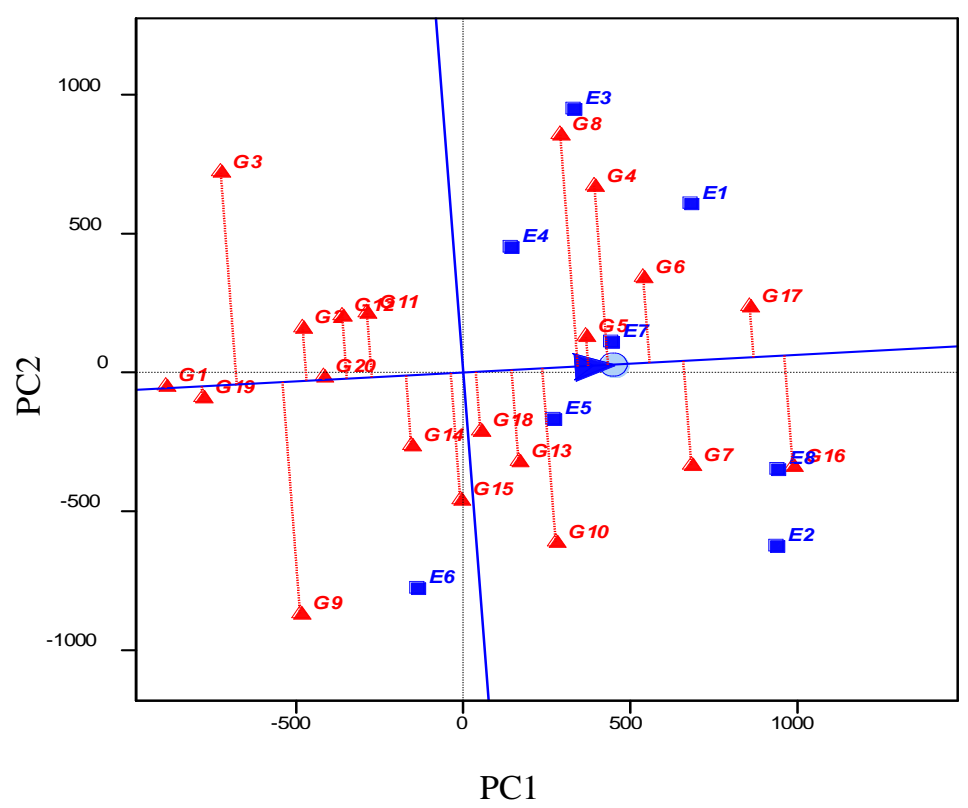

شكل r- مقايسه و رتبهندى لاينهاى اميدبخش سويا بر اساس عملكرد دانه و بايدارى در باى يلات مختصات محيط متوسط (AEC)

Fig. 2. Comparison and ranking of soybean purelines based on seed yield and stability in average environment coordinate biplot (AEC) 


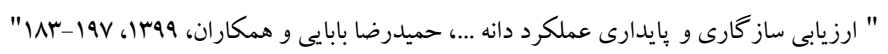

كيلو گرم در هكتار و يّ از آن لايسن G16 بـا عملكرد TVD.

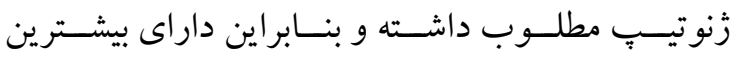

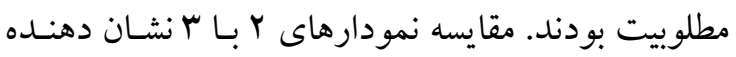

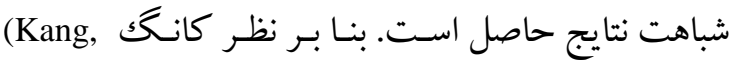
1993)

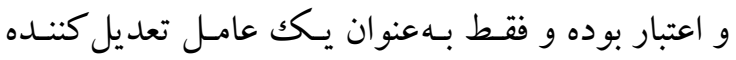

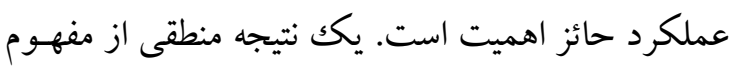

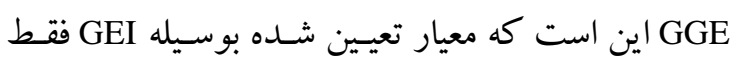

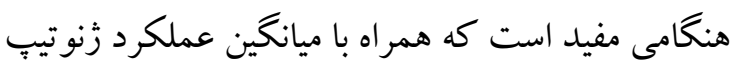

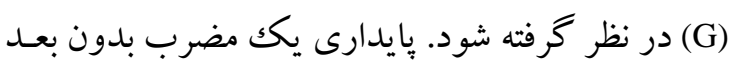

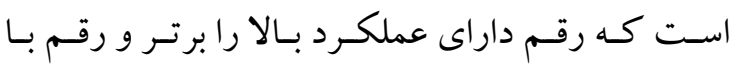
عملكرد يايين را بدتر نشان مىدهـد (Yan et al., 2003).

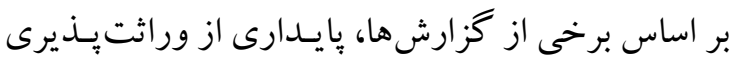

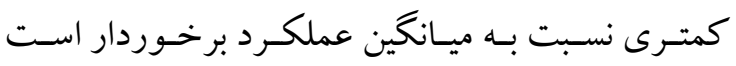
G7 (Eskridge, 1996)
رى برخوردار بود (شكل Y). زنو تيبهـاى G6 و G5 نيـز

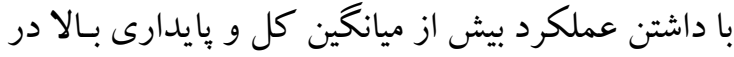

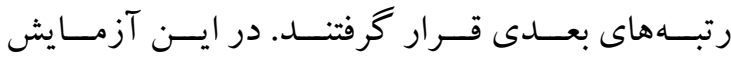

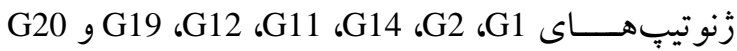
يايدارى خوبى داشتند، اما عملكرد آنها كمتر از ميانگين

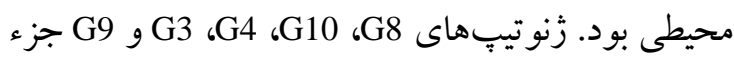

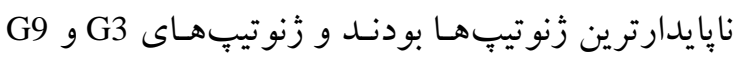

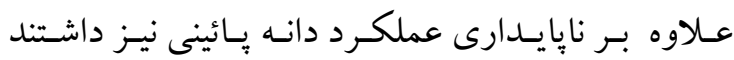

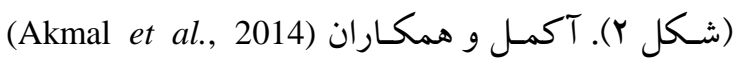

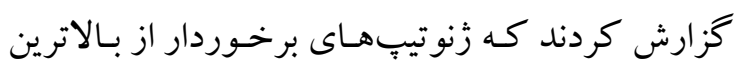

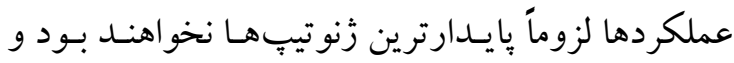

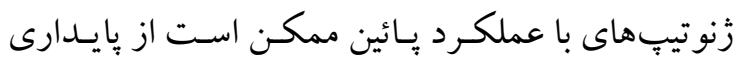

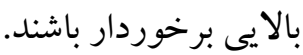

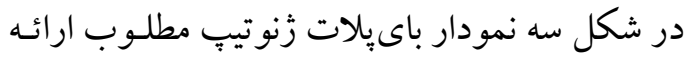

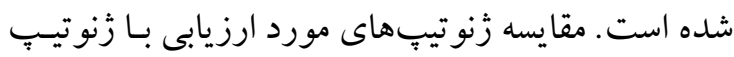

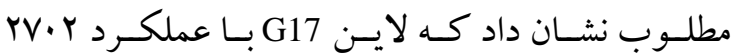

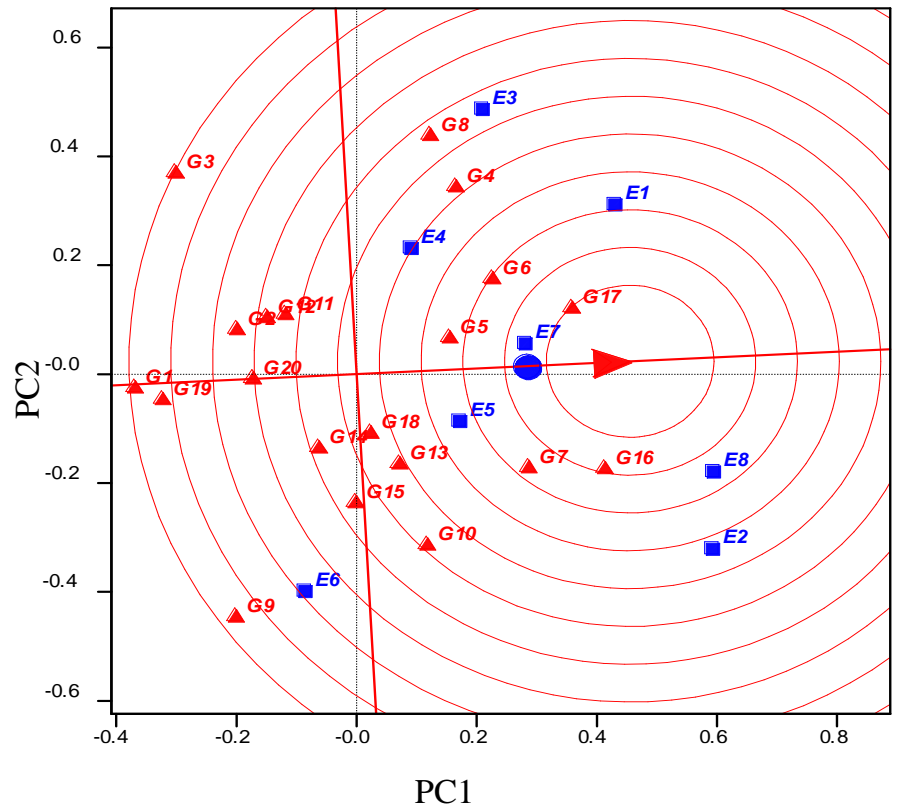

شكل ץ- مقايسه و رتبهبندى لاينهاى اميدبخش سويا بر اساس عملكرد دانه و بِيدارى در نماى باى يلات زنوتيب مطلوب و محيط مطلوب سوب برس

Fig. 3. Comparison and ranking of soybean purelines based on seed yield and stability in the ideal genotype and ideal environment biplot veiw 
اهميـت اسـت كـه عملكـــ زمنو تيبهــا در محيطهـاى مربوط به يكك محيط كـلان بطور مشـابهى قابـل تكرار اسـت (Crossa et al., 2002). در روش نمـودارى GGE)

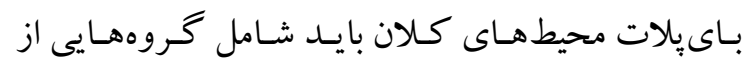

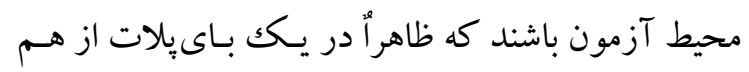

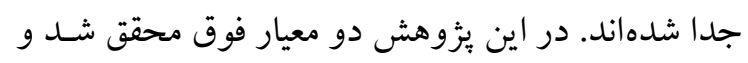

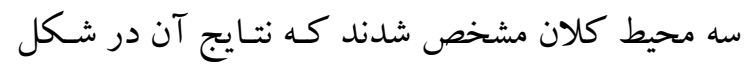

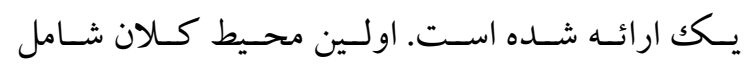

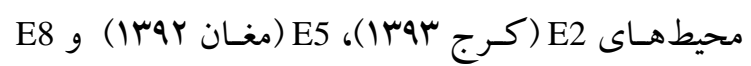

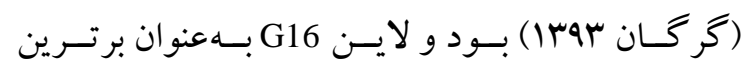

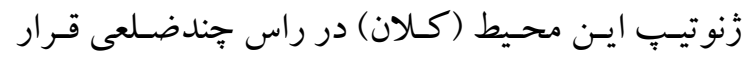

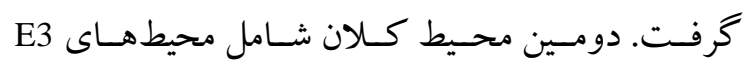

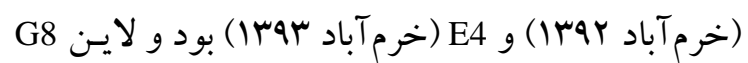
برترين زنوتيِ اين محيط (كلان) بود و سـومين محسيط

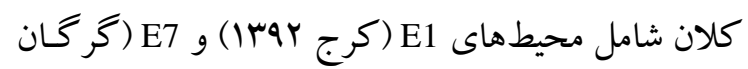

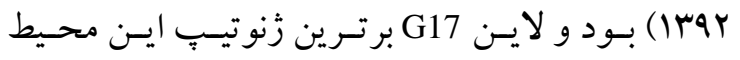

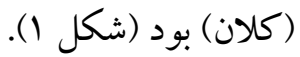

و G6 از حيث مطلوبيت در جايگاه سـوم و جهارم قـرار

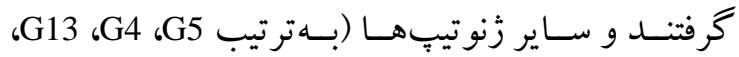

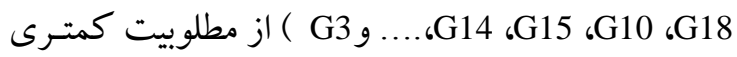

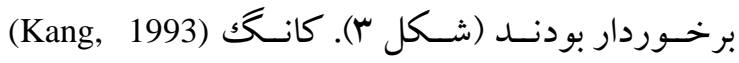
كزارش كرده اسـت كـه رتبهبنـدى زنو تيبّهـا براسـاس

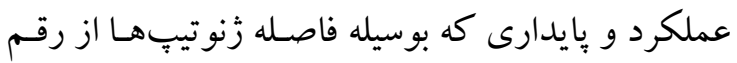

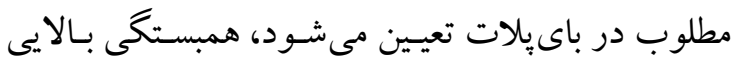

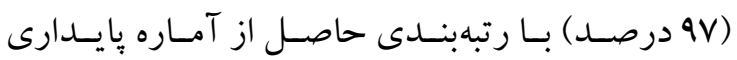
عملكرد (Ysi) دارد. در شكل يـك تشكيل دو محيط كـلان نشـان داده

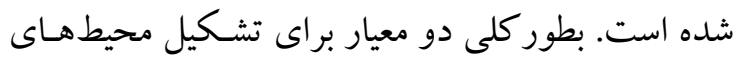

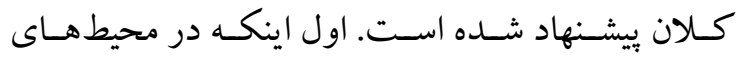
مختلف آزمايشى، ارقام برتر شناسايى شوند و دوم اينكه

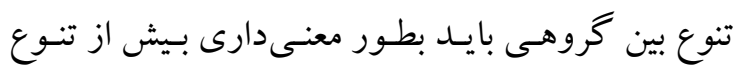

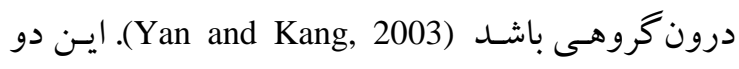

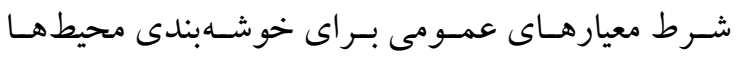

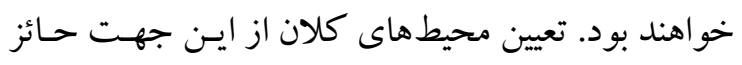

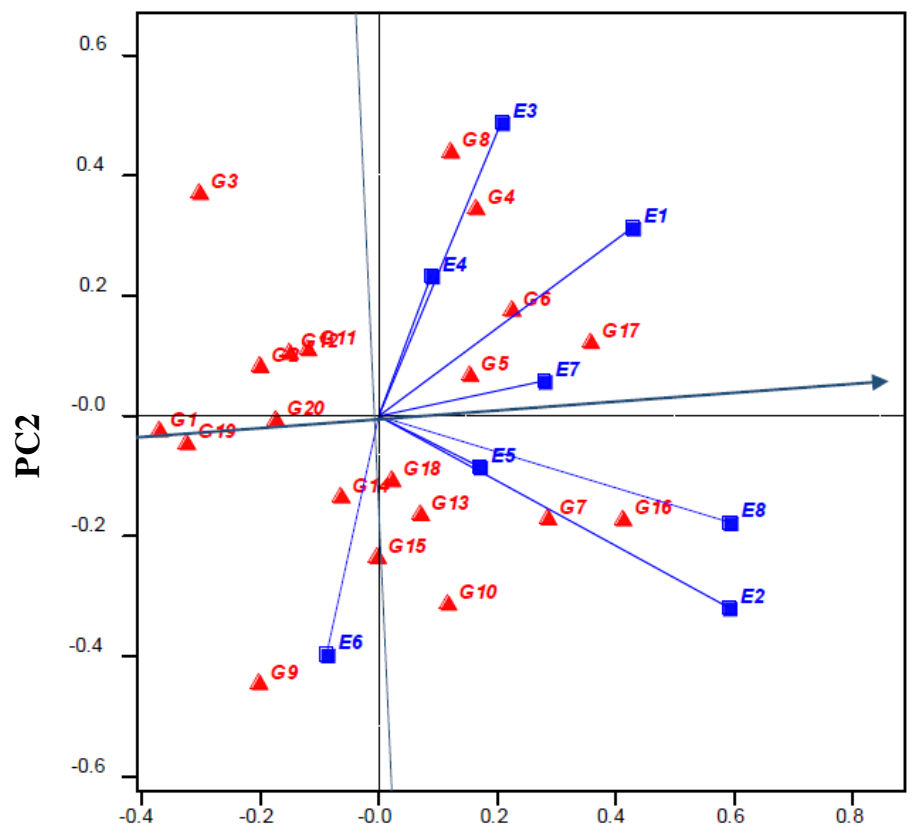

PC1

شكل F - روابط متقابل بين محيطهاى آزمايشى در نماى بردارى GGE باى يلات

Fig. 4. Interactions between experimental environments in the GGE Biplot veiw 
متو سط بود، به عبارت ديكر اين محيط همبستكى مثبـت بالايى با محيط متوسط داشت و نسبت به سـاير محيطهـا قابليت نمايندكى بيشترى از مناطق هدف داشت (شكل

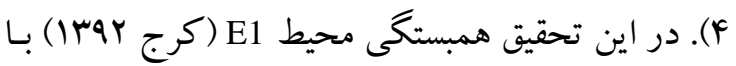

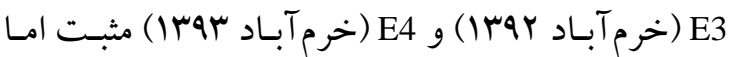

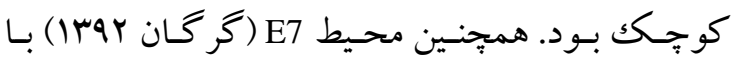
محيطهاى E3 (خرم آباد بqس|) و E4 (خرم آبـاد سوسا) همبستگى مثبت ولى جزئى داشتند. همبستكى محيط (مغان سوسا) نيز با E3 (خرم آباد rar) و E4 (خرم آباد

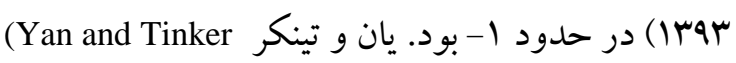
(2006 , گز ارش دادند كه زاويه كو جّك تر بين دو بردار محيطى نشان دهنده همبستخى بالاى دو محيط و زاويسه

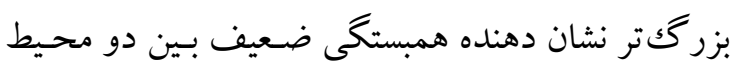
اسـت. در ايسن آزمـايش مشـخص شـد كـه طـول بـردار

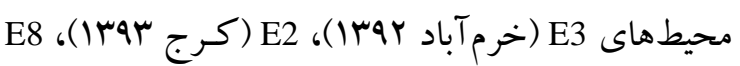

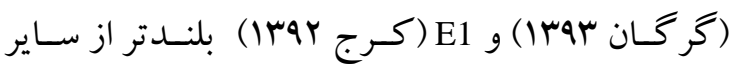
محيط ها بود و بنابر اين قابليت تمـايز بيشـترى داشـته و از توانايى بالاترى در تشخيص زنوتيٍِهاى برتر برخـوردار

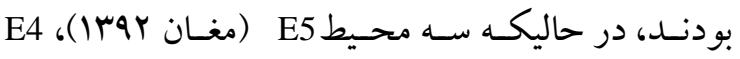

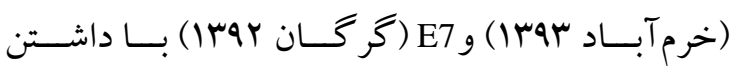
بردارهـاى كوتـاهتر، تـوان تمـايز كمتـرى در شناسـايى زَنو تيڤهاى برتر داشتند (شكل \&). در شكل سه علاوه بـر زنوتيـٍ مطلـوب، بـاى بِات محيط مطلوب نيز نشان داده شده است. محسيط مطلـوب محيطى است فرضـى كـه داراى حـداكثر قابليـت تمـايز

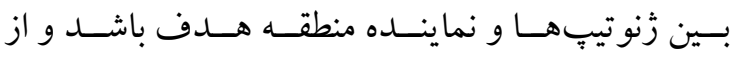

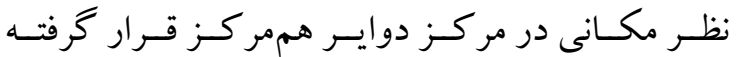

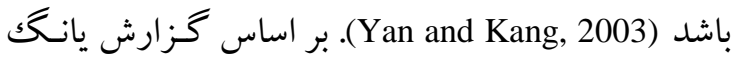
و همكـاران (Yang et al., 2009) يـك محسط مطلـوب بايد مقدار بالاى PC1 (قدرت تشخيص زنوتيب برتر ) و مقدار صفر PC2 ( قابليت نمايندكى براى كليه محيطها)

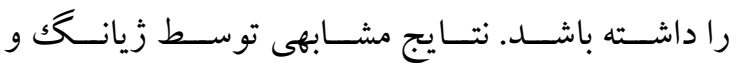
همكاران (Zhang et al, 2006) و بهـارتيو او همكاران (Bhartiya et al, 2017)
در شكل جهار بـاى بـلات همبستـى محيطى نشـان داده شده است. زاويه بين بردارهـاى محيطى تقريبى از همبستگى بين محيطها است و طول بـردار بـر آوردى از انحر اف معيار درون هر محيط و شاخصسى بـراى قابليـت

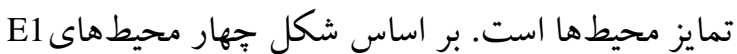

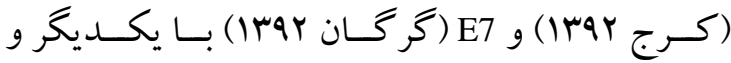

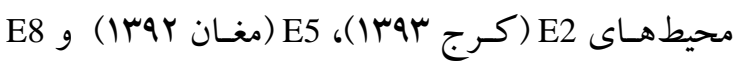

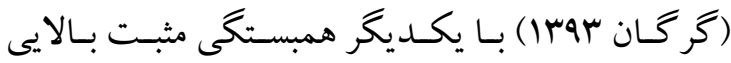
داشتند. دو محيط E3 (خرم آبـاد Yوسا) و E4 (خرم آبـاد سوس|) نيز همبستكى مثبت و بالايى داشتند كه با نمـودار محيطهاى كلان در شكل يكك نيز مشـابهت داشـت. دو محيط E3 و E4 (خرم آباد بوسا و دوم) در يكك محيط كـلان قــرار كرفتنـد. از آنجـا كـهـهــايج بهوا و دوم خرم آباد مشابه بود، مى توان با هدف كاهش هزينسها بـه انجام آزمايش يكساله اكتفا نمود. (Yan and Rajcan, در همين ارتبـاط يـان و رجكـان

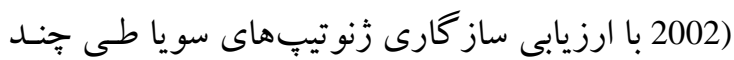
سال در جهار منطقه در كانادا گزارش نمودند كه يكى

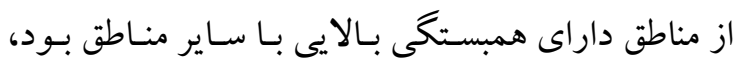

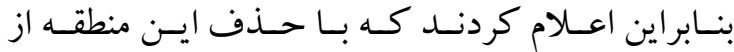
آزمايشـات، ضـمن كـاهش هزينـه كــارايى اصـلاحى افزايش خواهد يافت. بـر اسـاس نظرات ون ايسوويج و ايلكرســما (Van Euwijk and Elgersma, 1993) و ماكينده و آريـو (Makinde and Ariyo, 2011)، واكـنش

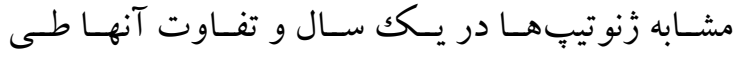
سالهاى مختلف نشان دهنــده ايسن اسـت كـه اطلاعـات هو اشناسى و اقليمى مى تواند در كروهبندى زنوتيبٍ ها بر اساس مقادير اثر متقابل زنوتيّ × سال مفيد باشد. يان و كانگك (Yan and Kang, 2003) گزارش دادند كه زاويـهـ هر بـردار محيطى بـا محسور مختصـات محسيط متوسـط، معيارى براى تعيين ميزان نمايندكى آن محيط اسـت. در

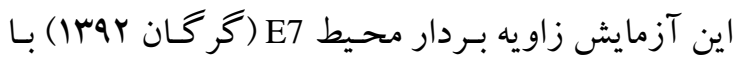
محور مختصات محيط متوسط (دايره كوجّك) كمتر از زاويه بردارى محيط هاى ديخر با محور مختصات محيط 
بر اساس عملكرد دانسه آن در محيط E3 و زنوتيٍِهـى E6 G4 G8 رابر اساس عملكرد دانسه آنها در محسيط حذف نمود.

\section{نتيجه كيرى}

در اين تحقيق زنوتيبه هاى سوياى مورد ارزيـابى بـه دليل زمينه زنتيكى غير مشابه ساز كارىهاى متفـاوتى در محيطهاى آزمايشىى نشـان دادنـد، امـا بطور كلى لايسن

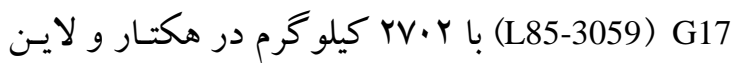
(L12/Chaleston × Mostang) G16

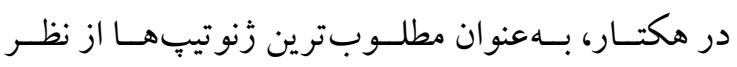
عملكـرد دانـه و بايسـارى شـناخته شـدند. نتـايج تجزيسه

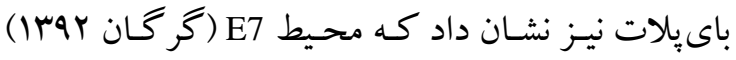

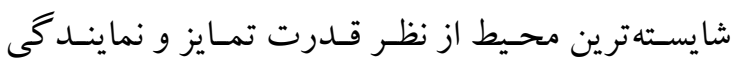
منطقه هدف بود.

\section{سياسگزارى}

بدين وسيله از موسسه تحقيقات اصلاح وتهيه نهال و بذر، بويزه بخش تحقيقات دانسهاى روغنسى كـه امكـان انجام آزمايشات را فراهم نمودند، كمال تشكر راداريم. همجينين از كليه همكاران محتر بخش دانههاى روغنى موسسه بويزه آقايان اوجانى و نواب و همكاران كرامى مراكز و ايستخاههاى تحقيقاتى گر گان، مغان و خرم آباد بخاطر تلاش مستمر در اجراى دقيق آزمايشات تشكر و قدردانى مى شود.
مطلوبيت محيط به فاصله آن از محـيط مطلـوب بستخى دارد. مقايسه محيطهاى مورد بررسى با محيط مطلـوب نشـان داد كـه محسط E7 (كر گـان بوسبا) نزديـك ترين محيط به محيط مطلوب بوده و موثرترين محيط از حيث تمايز و نماينـدكى اسـت. بـس از ايسن محسيط بـه ترتيب

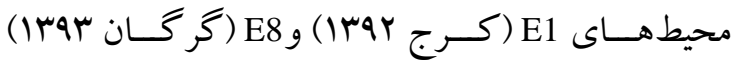
داراى كمترين فاصـله بـا محسط مطلـوب بـوده و داراى

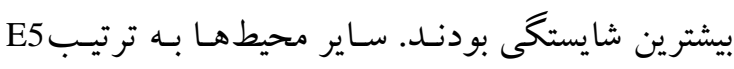

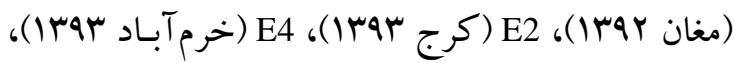
E3 (خرم آبـاد rar I ) وE6 (مغـان سوس ا ) از مطلوبيـت كمتــرى برخــوردار بــوده و در رتبـههاى بعـدى قــرار

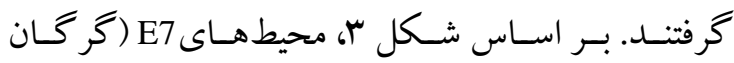

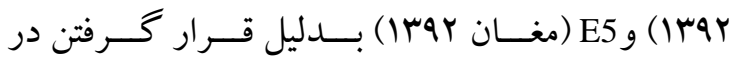
مجــاورت محسـور محسيط متوســ (دايــره كوجـكـ)

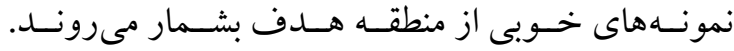

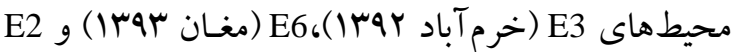

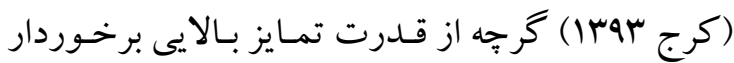
بودند (شكل \&)، اما به دليل قرارگرفتن در فاصله دورتـر از محور مختصات محيط متوسط (AEC)، نماينده خوبى از محسيط هـدف بـه حسـاب نمى آينـد، بــا ايسن وجـود

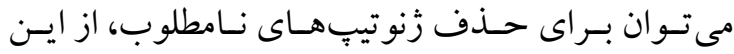
محيطها استفاده كرد. جنين محيطهـاى متمايز كنتـدهاى

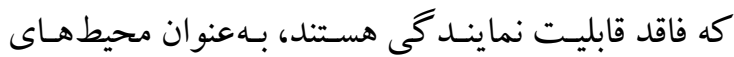
(Yan et al., كشنده يا حذف كننده نيـز تلقـى مىشـوند

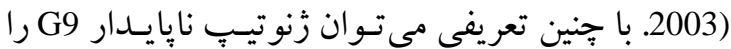

\section{References}

Akmal, C. M. Gunarsih and M. Y. Samaullah. 2014. Adaptation and stability of aromatic rice lines in North Sumatera (in Indonesian). Food Crop Res. J. 33 (1): 9-16

Alake, C. O. and O. J. Ariyo. 2012. Comparative analysis of genotype $\times$ environment interaction techniques in West African okra. J. Agric. Sci. 4(4): 135-150.

Amira, J. O., D. K. Ojo, O. J. Ariyo, O. A. Oduwaye and M. A. Ayo-Vaughan. 2013. Relative discriminating powers of GGE and AMMI models in the selection of tropical soybean genotypes. Afr. Crop Sci. J. 21 (1): $67-73$. 


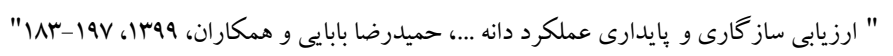

Atnaf, M., S. Kidane, S. Abadi and Z. Fisha. 2013. GGE biplots to analyse soybean multi-environment yield trial data in north Western Ethiopia. J. Plant Breed. Crop Sci. 5: 245-254.

Babaei, H. R., M. Bagheri and N. Razmi. 2016. Study on adaptability of new soybean pure lines. Registered Final Report of Research Project (Registeration number: 55194 - 5.3.2019). Agricultural Research, Education and Extension Organization (AREEO). (In Persian with English abstract).

Basford, K. E. and M. Cooper. 1998. Genotype by environment interactions and some considerations of their implication for wheat breeding in Australia. Aust. J. Agric. Res. 49: 154-175.

Bhartiya, A., J. P. Aditya, K. S. Pushpendra, J. P. Purwar and A. Agarwal. 2017. AMMI \& GGE biplot analysis of multi environment yield trial of soybean in North Western Himalayan state Uttarakhand of India. Legume Res. J. 40 (2): 306-312.

Chaudhary, K. J. and J. Wu. 2012. Stability analysis for yield and seed quality of soybean (Glycine max) across different environment in eastern South Dakota. Annual Conference on Applied Statistics in Agriculture [Online]. Available at http://newprairiepress.org/agstatconference/2012/proceedings/11

Crossa, J., P. L. Cornelius and W. Yan. 2002. Biplots of linear-bilinear models for studying crossover genotype $\times$ environment interaction. Crop Sci. 42 (2): 619- 633.

Eberhart, S. A. And W. A. Russel.1966. Stability parameters for comparing varieties. Crop Sci. 6: 36-40.

Eskridge, K. M. 1996. Analysis of multi environment trial using the probability of outperforming a check. p. 273 -307. In: M. S. Kang and Guach, J., (Eds.) Genotype by Environment Interaction. CRC Press.

Finlay, K. W. and G. N. Wilkinson. 1963. The analysis of adaptation in a plant breeding program. Aust. J. Agric. Res. 14: $742-754$.

Jandong E. A., M. I. Uguru and B. C. Oyiga. 2011. Determination of yield stability of seven soybean (Glycine max) genotypes across diverse soil pH levels using GGE biplot analysis. J. Appl. Bio. Sci. 43: 2924- 2941.

Kang, M. S. 1993. Simultaneous selection for yield and stability in crop performance Trials. Consequences for growers. Agron. J. 85: 754 -757.

Karakus, M. and U. A. Yildirim. 2019. GGE biplot analysis of genotype $\times$ environment interaction in soybean grown as a second crop. Turk. J. Field Crops. 24(2): 145-154.

Kocaturk, M, P. Cubuku, A. T. Goksoy, M. Sincik, E. Ilke, A. Kadiroglu, Y. Vurarak, Y. Sahin, M.

Mohammadi, R., M. Armion, H. Esmaeilzadeh, M. Eskandari. 2013. Analysis of genotype $\times$ environment interaction for grain yield in rainfed durum wheat. Iran. J. Dryland Agric. J. 4 (1): 1-16 (in Persian with English abstract).

Makinde S.C. O. and O. J. Ariyo. 2011. Analysis of genotypex environment interaction of groundnut (Arachis hypogaea L.). Malaysian J. Appl. Biol. 40 (2): 19-26.

Payne, R. W., S. A. Harding, D. A. Murray and D. M. Soutar. 2009. GenStat Release 12. Published by VSN International, 5 The Waterhouse, Waterhouse Street, Hemel Hempstead, Hertfordshire HP1 1ES, UK. 


$$
\text { "نشريه علوم زراعى ايران"، جلد بيست و دوم، شماره ب، تابستان ب99| }
$$

Pourdad, S. S. and M. Jamshid-Mogaddam .2013. Study on genotype $\times$ environment interaction through GGE Biplot for seed yield in spring rapeseed (Brassica Napus L.) in rainfed condition. J. Crop Breed. 12(5): 1- 14 (in Persian with English abstract).

Ramos, J. E. U., R. L. Brogin, V. P. C. Godinho, F. J. E. Botelho, F. D. Tardin and P. E. Teodoro. 2017. Identification of soybean genotypes with high stability for the Brazilian macro-region 402 via biplot analysis. Genet. Mol. Res. 16(3): 1-10.

Silveira, D. A., L. F. Pricinotto, M. Nardino, C. A. Bahry, C. E. Cavenaghi Prete and L. Cruz. 2016. Determination of the adaptability and stability of soybean cultivars in different locations and at different sowing times in Parana state using the AMMI and Eberhart and Russel methods [Online]. Available at https://www.researchgate.net/publication/311849977

Van Euwijk F. A., A. Elgersma. 1993. Incorporating environmental information in an analysis of $\mathrm{G} \times \mathrm{E}$ interaction for seed yield in perennial ryegrass. Heredity, 70: 447-457.

Yan, W. 1999. The interconnectedness among the traits of wheat and its implication in breeding for higher yield. Cereal Crops. (1): 43 - 45.

Yan, W. 2000. Singular-value partitioning in biplot analysis of multi- environment trial data. Agron. J. 94: 990 - 996.

Yan, W. and I. Rajcan. 2002. Biplot analysis of sites and trait relations of soybean in Ontario. Crop Sci. 42: 11-20.

Yan, W. and M. S. Kang. 2003. GGE Biplot Analysis: A Graphical Tool for Breeders, Geneticists and Agronomists. CRC Press.

Yan, W., M. S. Kang, B. Ma, S. woods and P. L. Cornelius. 2007. GGE biplot vs. AMMI analysis of genotype by environment data. Crop Sci. 47: 643 - 655.

Yang, R., J. Crossa, P. L. Cornelius and J. Burgueno. 2009. Biplot analysis of GEI effect. Crop Sci. 49: 1564-1576.

Yan, W. and N. A. Tinker. 2006. Biplot analysis of multi-environment trial data: Principles and applications. Can. J. Plant Sci. 86: 623-645.

Zhang, M., M. S. Kang, P. F. Reese Jr and H. L. Bhardwaj. 2006. Soybean cultivar evaluation via GGE biplot analysis. J. New Seeds. 7 (4): 37-50. 


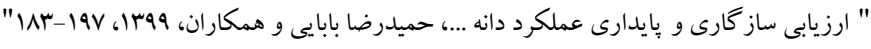

\title{
Evaluation of adaptability and seed yield stability of soybean (Glycine max L. Merril) promising lines using GGE biplot analysis
}

\author{
Babaei, H. R. ${ }^{1}$, N. Razmi ${ }^{2}$, S. Raeisi ${ }^{3}$ and H. Sabzi ${ }^{4}$
}

\begin{abstract}
Babaei, H. R., N. Razmi, S. Raeisi and H. Sabzi. 2020. Evaluation of adaptability and seed yield stability of soybean (Glycine $\max$ L. Merril) promising lines using GGE biplot analysis. Iranian Journal of Crop Sciences. 22(2): 183-197. (In Persian).
\end{abstract}

Selection of adapted genotypes with high seed yield and yield stability is the goal of soybean breeding programs. To evaluate the adaptability and seed yield stability of soybean promising lines, 19 promising lines and cv. Williams as check were evaluated using randomized complete block design with four replications in four locations: Karaj, Gorgan, Moghan and Khoramabad in Iran during two growing seasons (2013 and 2014). GGE biplot analysis was employed to evaluate the adaptability and seed yield stability. Combined analysis of variance showed thatyear, location, genotype, year $\times$ location, year $\times$ genotype, location $\times$ genotype and genotype $\times$ location $\times$ year interaction effects were significant on studied traits. The contribution of year, location and genotype variance to total variance was $0.01,0.60$ and 0.02 , respectively, indicating considerable contribution of location variance. The first two components of PC1 and PC2 explained overall $58 \%$ of total observed variation of genotype and genotype $\times$ environment $(G+G E)$. In this study, three mega-environments were identified. The first mega-environment included: E2 (Karaj 2014), E5 (Moghan 2013) and E8 (Gorgan 2014) and G16 was the superior genotype in this mega-environment. The second mega-environment included: E3 (Khorramabad 2013) and E4 (Khorramabad 2014) and G8 was the superior genotype in this mega-environment. Third megaenvironment consisted: E1 (Karaj 2013) and E7 (Gorgan 2013) and G17 was the superior genotype in this megaenvironment. Biplot analysis showed that genotypes: G17 (L85-3059) with $2702 \mathrm{~kg}^{-h^{-1}}$ and G16 (L12/Chaleston $\times$ Mustang) with $2750 \mathrm{~kg} \cdot \mathrm{ha}^{-1}$ were highly adapted genotypes with high seed yield and yield stability. The E7 environment (Gorgan, 2013) was the most desirable environment in respect to its discriminating ability among soybean genotypes and the best representative of the target environments.

Key words: Desirable environment, Desirable genotype, GGE biplot analysis and Genotype $\times$ environment interaction.

\footnotetext{
Received: August, $2019 \quad$ Accepted: July, 2020

1. Assistant Prof., Field and Horticultural Crops Sciences Research Department, Khorasan Razavi Agricultural and Natural Resources Research and Education Center, AREEO, Mashhad, Iran (Corresponding author)

(Email: 30241hrbabaei@gmail.com)

2. Assistant Prof., Field and Horticultural Crops Sciences Research Department of Agricultural and Natural Resources Research and Education Center of Ardabil (Parsabad Moghan), AREEO, Parsabad Moghan, Iran

3. Assistant Prof., Field and Horticultural Crops Sciences Research DepartmentAgricultural and Natural Resources Research and Education Center of Golestan, , Gorgan, Iran

4. Researcher. Field and Horticultural Crops Sciences Research Department, Agricultural and Natural Resources Research and Education Center of Lorestan, AREEO, Khoramabad, Iran
} 